\title{
Invited Review: Pathology, Etiology, Prevention, and Treatment of Fatty Liver in Dairy Cows*
}

\author{
G. Bobe, J. W. Young, and D. C. Beitz \\ Nutritional Physiology Group, \\ Department of Animal Science, \\ lowa State University, Ames 50011-3150
}

\section{ABSTRACT}

Fatty liver (i.e., hepatic lipidosis) is a major metabolic disorder of many dairy cows in early lactation and is associated with decreased health status and reproductive performance. In severe cases, milk production and feed intake are decreased. Therefore, a practical preventative or an efficacious treatment of fatty liver could save millions of dollars yearly in treatment, replacement, and production losses for dairy farmers. Fatty liver develops when the hepatic uptake of lipids exceeds the oxidation and secretion of lipids by the liver, which usually is preceded by high concentrations of plasma NEFA mobilized from adipose tissue. Excess lipids are stored as triacylglycerol in the liver and are associated with decreased metabolic functions of the liver. Liver can be categorized into normal liver or mild, moderate, or severe fatty liver; the latter can be subdivided further into nonencephalopathic severe fatty liver and hepatic encephalopathy. Insufficient or unbalanced dietary intake, obesity, and elevated estrogen concentrations are involved in the etiology of fatty liver, which is associated with greater incidence of dystocia, diseases, infections, and inflammations. Because even mild fatty liver is associated with decreased health status and reproductive performance of dairy cows, prevention of fatty liver by supplying cows with sufficient nutrients and a clean and health-promoting environment in the peripartal period would reduce production losses of cows more than would any treatment of fatty liver. This, however, might not be enough for cows that are obese or do not eat well, had calving difficulties or twins, have metabolic or infectious diseases, or are in severe negative energy balance because of high milk production immediately after calving. Potential and commonly used preventatives, as well as treatments, are discussed in the review. Currently, detection of fatty liver is possible only by

Received January 13, 2003.

Accepted June 30, 2004.

Corresponding author: D. C. Beitz; e-mail: dcbeitz@iastate.edu.

*Publication of the Iowa Agriculture and Home Economics Experiment Station, Ames; Project Number 3801. minor surgery. Ultrasonic techniques offer a potential tool to noninvasively detect fatty liver. Future genearray and proteomic studies may provide means to detect early molecular events in the etiology of fatty liver plus their connection with immune function and reproductive performance so that more effective treatments and preventatives of fatty liver can be developed. Such advances hopefully will make fatty liver a problem of the past.

(Key words: dairy cow, fatty liver, metabolic disorder, diseases)

Abbreviation key: HDL = high-density lipoprotein, $\mathbf{L D L}=$ low-density lipoprotein, $\mathbf{T A G}=$ triacylglycerol, TNF $\boldsymbol{\alpha}=$ tumor necrosis factor alpha, VLDL = verylow-density lipoprotein.

\section{INTRODUCTION}

Fatty liver (i.e., hepatic lipidosis) is a major metabolic disorder of animals (Gruffat et al., 1996; Goff and Horst, 1997). It develops when the hepatic uptake of lipids exceeds the oxidation and secretion of lipids by the liver. Excess lipids are stored as triacylglycerol (TAG) in the liver and are associated with decreased metabolic functions of the liver (Grummer, 1993; Drackley, 1999). The condition is known as fatty liver or fat cow syndrome in cows (Gruffat et al., 1996). In dairy cows, fatty liver occurs primarily in the first 4 wk after calving (Grummer, 1993), when up to $50 \%$ of all cows have some accumulation of TAG in liver (Jorritsma et al., 2000, 2001). One reason is that dietary intake is insufficient to meet the increased requirements of energy for maintenance and lactation (Goff and Horst, 1997; Herdt, 2000). Thus, NEFA are mobilized from the adipose tissue, often in amounts greater than are needed by cows, and the excess is transported to the liver, especially in obese cows (McNamara, 2000). Hormonal changes and greater incidence of infections during parturition are other reasons for increased mobilization of NEFA from adipose tissue (Goff and Horst, 1997).

Fatty liver is associated with decreased health status, well-being, productivity, and reproductive performance of cows (Wensing et al., 1997). Therefore, fatty liver 
Table 1. Categories of fatty liver in dairy cows.

\begin{tabular}{llllll}
\hline & $\begin{array}{l}\text { Liver TAG } \\
\text { (\% wet weight) }\end{array}$ & $\begin{array}{l}\text { Urinary } \\
\text { ketones }\end{array}$ & $\begin{array}{l}\text { Feed intake, } \\
\text { milk production }\end{array}$ & $\begin{array}{l}\text { Health status, } \\
\text { reproductive } \\
\text { performance }\end{array}$ & Liver \\
\hline Normal & $<1 \%$ & $0^{2}$ & 0 & 0 & Normal \\
Mild fatty liver & $1-5 \%$ & + & 0 & - & $\begin{array}{l}\text { Centrilobular TAG infiltration } \\
\text { TAG infiltration throughout liver }\end{array}$ \\
Moderate fatty liver & $5-10 \%$ & ++ & 0 & -- & Enlarged, necrotic \\
\hline
\end{tabular}

${ }^{1} \mathrm{TAG}=$ triacylglycerol .

${ }^{2}$ The symbols + and - mean positive and negative association, respectively, and the number of symbols represents slight, moderate, or strong association; 0 means no association.

is associated with increased veterinary costs, longer calving intervals, decreased milk production, and decreased average lifetime of cows. The exact costs for fatty liver are difficult to estimate, because fatty liver currently can be diagnosed only by liver biopsy. The average costs and incidence rate of primary ketosis, a metabolic disorder that is closely associated with fatty liver (Veenhuizen et al., 1991), however, are estimated to be $\$ 145 /$ case (Guard, 1994) and $4.8 \%$, respectively (Kelton et al., 1998). Assuming 9 million dairy cows in the United States, the annual costs for fatty liver in the United States can be estimated to be over $\$ 60$ million. The pathology and etiology of fatty liver and ketosis have been studied for over 20 yr by our research group and many others to help provide additional basic understanding and to find possible preventatives and treatments for fatty liver. The primary objectives of this review are to describe concisely what is known about the pathology and etiology of fatty liver, and then to summarize current and potential preventatives and treatments for fatty liver and to discuss their limitations.

\section{CATEGORIES AND EPIDEMIOLOGY OF FATTY LIVER}

Fatty liver is evaluated either by chemical or histological analysis of liver samples for liver TAG or total lipid (Woltow et al., 1991). Generally, fatty liver can be defined on the basis of percentage of liver TAG or lipid that is associated with decreased health status, wellbeing, productivity, or reproductive performance of cows (Wensing et al., 1997). Fatty liver can be categorized into normal liver and mild, moderate, and severe fatty liver (Table 1). The proposed beginning and end points of categories vary between reports (Reid, 1980; Gerloff et al., 1986a) because the changes associated with increasing concentrations of liver TAG or lipid are not abrupt. Additionally, cows can respond differently at the same concentration of liver TAG because concentration of liver TAG is an indirect measurement for the effect of lipid droplets on the function of hepatocytes (Johannsen et al., 1993).

Severe or clinical fatty liver ( $>10 \%$ liver TAG on wet weight basis), which also is called fat cow or fat cow mobilization syndrome, often is preceded by elevated concentrations of urinary ketones, severe BW loss, and a feed intake that is depressed or much lower than required for milk production (Veenhuizen et al., 1991; Hippen et al., 1999; Jorritsma et al., 2001). Cows with severe fatty liver also can have decreased concentrations of glucocorticoids (Morrow et al., 1979). Results by Gerloff et al. (1986a) suggested that, in contrast to mild and moderate fatty liver, severe fatty liver develops prior to parturition and is associated with naturally elevated liver TAG concentrations; however, other studies could not confirm those results (van den Top et al., 1996). In extreme cases, cows develop hepatic encephalopathy, which is characterized by depressed consciousness, ataxia, somnolency, and coma (Rehage et al., 1999), and death can be caused by liver and kidney failure or cardiac arrest. The recovery rate from hepatic encephalopathy is less than $75 \%$, because some cows remain anorexic despite intensive treatment (Morrow et al., 1979; Gerloff et al., 1986a).

Cows with moderate fatty liver (5 to $10 \%$ liver TAG) and, to a smaller extent, mild fatty liver (1 to $5 \%$ liver TAG) also have elevated concentrations of urinary ketones but not to the same extent as cows with clinical fatty liver (Hippen et al., 1999). Cows with moderate or mild fatty liver generally have a more severe negative energy balance than do cows with normal liver $(<1 \%$ liver TAG; Jorritsma et al., 2001). Severe negative energy balance, fatty infiltration, and their physiological and metabolic associations are correlated positively with decreased health status and reproductive performance (Wensing et al., 1997). In the first month after calving, 5 to $10 \%$ of dairy cows have severe fatty liver and 30 to $40 \%$ have moderate fatty liver (Table 2), which indicates that up to $50 \%$ of dairy cows are at a higher risk for diseases and reproductive problems. Therefore, a better understanding of the pathology and etiology of 
Table 2. Incidence of different categories of fatty liver in dairy cows.

\begin{tabular}{lllll}
\hline $\begin{array}{l}\text { Category of } \\
\text { fatty liver }\end{array}$ & Incidence & Country & Breed of cows & Reference \\
\hline $\begin{array}{l}\text { Moderate } \\
\text { Severe }\end{array}$ & $48 \%$ & England & Holstein & Reid, 1980 \\
$\begin{array}{l}\text { Moderate } \\
\text { Severe }\end{array}$ & $15 \%$ & England & Guernsey & Reid, 1980 \\
$\begin{array}{l}\text { Severe } \\
\text { Moderate }\end{array}$ & $53 \%$ & Finland & Ayrshire & Gröhn et al., 1987 \\
$\begin{array}{l}\text { Severe } \\
\text { Moderate }\end{array}$ & $15 \%$ & France & n.r. & Mazur et al., 1988 \\
$\begin{array}{l}\text { Severe } \\
\text { Moderate }\end{array}$ & $5 \%$ & Germany & n.r. & Schäfer et al., 1991 \\
$\begin{array}{l}\text { Severe } \\
\text { Moderate }\end{array}$ & $20 \%$ & Japan & Holstein & Acorda et al., 1995 \\
$\begin{array}{l}\text { Moderate } \\
\text { Severe }\end{array}$ & $11 \%$ & Netherlands & n.r. & Jorritsma et al., 2000 \\
$\begin{array}{l}\text { Moderate } \\
\text { Severe }\end{array}$ & $45 \%$ & Netherlands & n.r. & Jorritsma et al., 2001 \\
Severe & $14 \%$ & United States & n.r. & Gerloff et al., 1986a \\
\hline
\end{tabular}

${ }^{1}$ n.r. $=$ not reported.

fatty liver is important for greater profitability in the dairy industry.

\section{PATHOLOGY OF FATTY LIVER}

\section{Gross Pathology of Fatty Liver}

Excessive infiltration of lipids, or more specifically of TAG, causes gross and microscopic alterations of the liver that become more prominent with greater infiltration of lipids. The liver becomes enlarged and swollen and has round edges and a pale to yellow appearance (Kapp et al., 1979; Morrow et al., 1979). Adrenal glands, kidneys, and cardiac and skeletal muscles also can be infiltrated with excessive amounts of TAG (Kapp et al., 1979; Morrow et al., 1979; Reid and Roberts, 1982). Other gross pathological findings in cows with severe fatty liver are a) myocarditis; b) necrosis in renal, ovarian, muscle, and uterine tissues; c) necrosis and involution of the pituitary gland; d) involution of the pancreas and lymphatic system; and e) necrosis, inflammation, and ulceration of the gastrointestinal tract (Kapp et al., 1979; Morrow et al., 1979; Reid and Roberts, 1982).

\section{Histological and Metabolic Pathology of Fatty Liver}

Histological findings in cows with fatty liver include a) fatty cysts in liver parenchyma; b) increased volume of individual hepatocytes; c) mitochondrial damage; d) compression and decreased volume of nuclei, rough endoplasmic reticulum, sinusoids, and other organelles; and e) decreased number of organelles (Kapp et al., 1979; Reid and Collins, 1980; Johannsen et al., 1993). Accumulation of TAG in cows with mild fatty liver is limited to the centrilobular section of the liver near the hepatic vein, but the accumulation extends to the midzonal section and then spreads to the periportal sections in cows with moderate and severe fatty liver (Reid and Collins, 1980; Veenhuizen et al., 1991). The microscopic alterations affect cellular integrity and function of hepatocytes and, therefore, cause necrosis and cellular leakage, particularly in cows with severe fatty liver, which is demonstrated by increased concentrations of liver enzymes and bile constituents in plasma (Table 3).

Concentrations of enzymes in plasma that are in greater concentrations in liver than in other tissues are increased the most. Increased concentrations of bile constituents (bilirubin, bile acids, and cholic acid) in plasma indicate that bile flow is decreased in cows with fatty liver. Bile, therefore, accumulates in the liver, which is indicated by the effectiveness of choleretic agents in treatment of fatty liver (Fürll et al., 1993). In humans, high concentrations of bile are toxic and increase the production of free radicals in the liver, which can cause inflammation and tissue damage (Ljubuncic et al., 2000). In cattle, high concentrations of bile cause tissue damage to bovine pancreatic duct epithelial cells in culture (Alvarez et al., 1997). Increased concentrations of free radicals in the liver of cows are indicated by elevated concentrations of malondialdehyde, one of the end products of lipid peroxidation, and decreased concentrations of $\alpha$-tocopherol (Mudron et al., 1999), an antioxidant, in plasma (Table 3) and to a smaller extent in the liver.

Increased concentrations of liver TAG are accompanied by decreased concentrations of structural lipids (free cholesterol, cholesteryl ester, and phospholipids), energy precursors (citrate), and energy storage mole- 
Table 3. Association of fatty liver with concentrations of liver constituents in plasma of lactating dairy cows.

\begin{tabular}{lll}
\hline Constituent & Association $^{1}$ & Reference \\
\hline Alkaline phosphatase & + & Staufenbiel et al., 1992; van den Top et al., 1996 \\
Alanine aminotransferase & + & Johannsen et al., 1988 \\
Alkaline phosphatase & + & Staufenbiel et al., 1992; van den Top et al., 1996 \\
Aspartate aminotransferase & ++ & Johannsen et al., 1992; van den Top et al., 1996 \\
Bilirubin & ++ & Reid et al., 1983; West, 1990 \\
Bile acid & ++ & Rehage et al., 1999 \\
Cholic acid & ++ & West, 1990 \\
$\gamma$-Glutamyl transferase & ++ & Rehage et al., 1996 \\
Glutamate dehydrogenase & +++ & Ohtsuka et al., 2001 \\
Lactate dehydrogenase & + & Wensing et al., 1997 \\
Malondialdehyde & ++ & Mudron et al., 1999 \\
Ornithine carbamoyl transferase & + & Gröhn et al., 1983; Reid et al., 1986 \\
Sorbitol dehydrogenase & + & Gröhn et al., 1983 \\
$\alpha$-Tocopherol & -- & Mudron et al., 1999 \\
\hline
\end{tabular}

${ }^{1}$ The symbols + and - mean increase and decrease, respectively, and the number of symbols represents slight, moderate, or strong association. The strength of association increases with increasing concentrations of triacylglycerol.

cules (glycogen) as shown in Table 4. Decreased concentrations of glycogen indicate an increased risk for metabolic disorders that are associated with fatty liver (Drackley et al., 1992). Therefore, they recommended using the ratio of liver TAG to liver glycogen, rather than liver TAG alone, as a diagnostic indicator for fatty liver. Fatty liver also is associated with elevated concentrations of NEFA, BHBA, and acetoacetate in blood, all of which can be cytotoxic at high concentrations.

Concentrations of proteins that are important in lipid packaging and secretion are affected by fatty liver (Table 4; Katoh, 2002) except for microsomal triacylglyceride transfer protein (Bremmer et al., 2000). Concentrations of apoprotein $\mathrm{B}$, which is the major protein of very-low-density lipoproteins (VLDL) and low-density lipoproteins (LDL; Gruffat et al., 1996; Katoh, 2002), protein kinase C (Table 4), which is involved in post- translational modification of apoprotein A-I (Katoh, 2002), and carnitine palmitoyltransferase in mitochondria, which is involved in $\beta$-oxidation and ketogenesis (Mizutani et al., 1999), are decreased in liver. Concentrations of plasma lipids, lipoproteins (apoproteins AI, B-100, and C-III), and enzymes (lecithin-cholesterol acyltransferase) involved in lipid transport also are decreased in cows with fatty liver (Table 5), which indicates decreased secretion of lipoproteins, specifically of VLDL (Katoh, 2002). On the basis of clinical and histological findings, possible mechanisms for decreased VLDL secretion in cows with fatty liver could be a) decreased VLDL transport from endoplasmic reticulum to golgi apparatus, b) alteration of glycosylation of apoprotein B-100, c) decreased formation of secretory vesicles, and d) decreased migration of secretory vesi-

Table 4. Association of fatty liver with liver composition in lactating dairy cows.

\begin{tabular}{lll}
\hline Constituent & Association ${ }^{1}$ & Reference \\
\hline Acetoacetate & ++ & Mills et al., 1986 \\
Apoprotein B & - & Gruffat et al., 1997 \\
BHBA & ++ & Mills et al., 1986 \\
Carnitine palmitoyltransferase & - & Mizutani et al., 1999 \\
Cholesterol, total & - & van den Top et al., 1996 \\
Cholesterol, free & - & Saarinen and Shaw, 1950; Brumby et al., 1975 \\
Cholesteryl ester & + & Saarinen and Shaw, 1950; Brumby et al., 1975 \\
Citrate & - & Johannsen et al., 1992; van den Top et al., 1996 \\
Glycogen & --- & Mudron et al., 1999 \\
Malondialdehyde & + & Bremmer et al., 2000 \\
Microsomal triacylglyceride transfer protein & 0 & Brumby et al., 1975 \\
NEFA & + & Brumby et al., 1975; van den Top et al., 1996 \\
Phospholipids & - & Katoh, 2002 \\
Protein kinase C & - & Brumby et al., 1975; van den Top et al., 1996 \\
Triacylglycerol & +++ &
\end{tabular}

\footnotetext{
${ }^{1}$ The symbols + and - mean increase and decrease, respectively, and the number of symbols represents slight, moderate, or strong association; 0 means no association. The strength of association increases with increasing concentrations of triacylglycerol.
} 
Table 5. Association of fatty liver with concentrations of compounds involved in lipid transport in plasma of lactating dairy cows.

\begin{tabular}{|c|c|c|}
\hline Constituent & Association $^{1}$ & Reference \\
\hline Apoprotein A-I & - & Bobowiec et al., 1997; Katoh, 2002 \\
\hline Apoprotein B-100 & - & Marcos et al., 1990; Katoh, 2002 \\
\hline Apoprotein C-III & - & Bobowiec et al., 1997; Katoh, 2002 \\
\hline Cholesterol, total & - & Herdt et al., 1983; Reid et al., 1983 \\
\hline Cholesterol, free & _- & Mazur et al., 1989; Katoh, 2002 \\
\hline Cholesteryl ester & - & Brumby et al., 1975; Katoh, 2002 \\
\hline VLDL $^{2}$-cholesterol & 0 & Rayssiguier et al., 1988; Bobowiec et al., 1997 \\
\hline $\mathrm{LDL}^{3}$-cholesterol & - & Mazur et al., 1989; Bobowiec et al., 1997 \\
\hline $\mathrm{HDL}^{4}$-cholesterol & 0 & Mazur et al., 1989; Bobowiec et al., 1997 \\
\hline Lecithin-cholesterol acyltransferase & - & Katoh, 2002 \\
\hline Phospholipids & - & Brumby et al., 1975; Katoh, 2002 \\
\hline VLDL-phospholipids & 0 & Rayssiguier et al., 1988; Bobowiec et al., 1997 \\
\hline LDL-phospholipids & - & Mazur et al., 1989; Bobowiec et al., 1997 \\
\hline HDL-phospholipids & - & Mazur et al., 1989; Bobowiec et al., 1997 \\
\hline Triacylglycerol & - & Katoh, 2002 \\
\hline VLDL-triacyglycerol & - & Bobowiec et al., 1997 \\
\hline LDL-triacyglycerol & - & Mazur et al., 1989; Bobowiec et al., 1997 \\
\hline HDL-triacylglycerol & 0 & Rayssiguier et al., 1988; Bobowiec et al., 1997 \\
\hline VLDL-protein & - & Bobowiec et al., 1997 \\
\hline LDL-protein & - & Mazur et al., 1989; Bobowiec et al., 1997 \\
\hline HDL-protein & + & Mazur et al., 1989; Bobowiec et al., 1997 \\
\hline
\end{tabular}

\footnotetext{
${ }^{1}$ The symbols + and - mean increase and decrease, respectively, and the number of symbols represents slight, moderate, or strong association; 0 means no association. The strength of association increases with increasing concentrations of triacylglycerol.

${ }^{2}$ Very-low-density lipoprotein.

${ }^{3}$ Low-density lipoprotein.

${ }^{4}$ High-density lipoprotein.
}

cles from golgi apparatus to cell membrane (Gruffat et al., 1996).

Fatty liver has detrimental effects on the physiological function of lipoproteins, in particular high-density lipoproteins (HDL; Katoh, 2002). In cows with fatty liver, HDL particles bind more haptoglobin and serum amyloid A, which decreases concentrations of apoprotein A-I and C-III in HDL particles (Katoh, 2002). Apoprotein A-I is responsible for activation of lecithin-cholesterol acyltransferase, which esterifies free cholesterol with phosphatidylcholine to form cholesteryl esters and lysophosphatidylcholine (Katoh, 2002). Cows with fatty liver, therefore, have decreased synthesis of cholesteryl esters, which are important precursors for the synthesis of steroids (Katoh, 2002).

Histological and compositional changes in fatty liver are associated with changes of carbohydrate, lipid, and protein metabolism in hepatocytes (Table 6). Increased infiltration of the liver by TAG is associated with decreased production of energy precursors (decreased gluconeogenesis and variable effects on ketogenesis and $\beta$-oxidation) and increased lipogenesis in the liver. Fur-

Table 6. Association of fatty liver with metabolic function in bovine hepatocytes and adipocytes.

\begin{tabular}{lll}
\hline Pathway & Association $^{1}$ & Reference \\
\hline Hepatocytes: & & \\
Gluconeogenesis & -- & Cardórniga-Valiño et al., 1997; Rukkwamsuk et al., 1999a \\
Insulin clearance & - & Strang et al., 1998b \\
Ketogenesis & \pm & Drackley et al., 1992 \\
Lipogenesis & +++ & Grum et al., 1996; Cadórniga-Valiño et al., 1997 \\
$\beta$-Oxidation & \pm & Grum et al., 1996; Cadórniga-Valiño et al., 1997 \\
Peroxisomal oxidation & - & Grum et al., 2002 \\
Ureagenesis & - & Strang et al., 1998a \\
Adipocytes: & 0 & Rukkwamsuk et al., 1999b \\
Lipogenesis & +++ & Rukkwamsuk et al., 1998 \\
Lipolysis & &
\end{tabular}

\footnotetext{
${ }^{1}$ The symbols,+- , and \pm mean increase, decrease, and variable association, respectively, and the number of symbols represents slight, moderate, or strong association; 0 means no association. The strength of association increases with increasing concentrations of triacylglycerol.
} 
Table 7. Association of fatty liver with plasma concentrations of hormones in lactating dairy cows.

\begin{tabular}{lll}
\hline Constituent & Association $^{1}$ & Reference \\
\hline Glucagon & - & de Boer et al., 1986 \\
Glucocorticoids & - & Morrow et al., 1979 \\
Growth hormone & + & de Boer et al., 1986 \\
IGF-1 & -- & Formigoni et al., 1996 \\
Insulin & \pm & de Boer et al., 1986; Holtenius and Holtenius, 1996 \\
Thyroxine & - & Kapp et al., 1979; Gerloff et al., 1986b \\
Triiodothyronine & - & Gerloff et al., 1986b \\
\hline
\end{tabular}

\footnotetext{
${ }^{1}$ The symbols,+- , and \pm mean increase, decrease, and variable association, respectively, and the number of symbols represents slight, moderate, or strong association. The strength of association increases with increasing concentrations of triacylglycerol.
}

thermore, ureagenesis and the ability of insulin to increase protein synthesis are decreased (Strang et al., 1998a), which can explain the elevated concentrations of plasma ammonia in cows with fatty liver (Rehage et al., 2001).

Fatty liver is associated with altered hormonal sensitivity of adipose tissue and the pancreas. Lipogenesis is promoted less by both insulin and glucose (Rukkwamsuk et al., 1999b). Lipolysis is inhibited less by glucose and BHBA (Rukkwamsuk et al., 1998). Clearance rates of insulin (Strang et al., 1998b), endotoxins (Breukink and Wensing, 1997), and other compounds in hepatocytes (West, 1990) and probably in other organs, and the uptake of glucose by peripheral tissues are all decreased (Ohtsuka et al., 2001).

Fatty liver is not only associated with changes in the hormonal sensitivity of tissues (Rukkwamsuk et al., $1998,1999 \mathrm{~b})$ but also with changes of the concentrations of hormones themselves. Because of the decreased clearance of hormones by hepatocytes infiltrated with lipids (Strang et al., 1998b), it can be assumed that synthesis or secretion of IGF-I by liver, glucocorticoids by the adrenal glands, glucagon and insulin by the pan- creas, and thyroxin and triiodothyronine by the thyroid glands are decreased (Table 7). Additionally, secretion of insulin by the pancreas is promoted less by glucose and glucagon (Hippen et al., 1999; She et al., 1999).

\section{Clinical Pathology of Fatty Liver}

The hormonal and pathological changes associated with fatty liver affect concentrations of metabolites and minerals in plasma (Table 8). Decreased concentrations of metabolites such as $\alpha$-amino $\mathrm{N}$ and glucose can decrease the functions of organs in cows with fatty liver, which is true also for the ketogenic branched-chain AA (Rehage et al., 2001).

Elevated concentrations of ammonia, NEFA, BHBA, and acetoacetate can decrease the physiological functions of organs because of their toxicity at high concentrations and because of their metabolic effects. Elevated concentrations of NEFA increase lipogenesis and ketogenesis in hepatocytes (Cadórniga-Valiño et al., 1997). High concentrations of BHBA and acetoacetate decrease rates of $\beta$-oxidation, gluconeogenesis, and the citric acid cycle in hepatocytes (Table 6).

Table 8. Association of fatty liver with concentrations of plasma metabolites and minerals in lactating dairy cows.

\begin{tabular}{lll}
\hline Constituent & Association & \\
\hline${ }^{1}$ & Reference \\
\hline Acetoacetate & +++ & de Boer et al., 1985; Staufenbiel et al., 1992 \\
Albumin & - & Reidt et al., 1983; West, 1990 \\
$\alpha$-Amino N & - & de Boer et al., 1985 \\
Ammonia & + & Zhu et al., 2000; Rehage et al., 2001 \\
BHBA & +++ & de Boer et al., 1985; Ohtsuka et al., 2001 \\
Branched-chain AA & - & Rehage et al., 1999, 2001 \\
Copper & + & Reid et al., 1986 \\
Glucose & \pm & Staufenbiel et al., 1992; Ohtsuka al., 2001 \\
Iron & - & Reid et al., 1986 \\
Magnesium & - & Reid et al., 1983, 1986 \\
NEFA & +++ & Gerloff et al., 1986a; Mazur et al., 1988 \\
Protein & - & Staufenbiel et al., 1992 \\
Urea N & - & West, 1990 \\
\hline
\end{tabular}

${ }^{1}$ The symbols + and - mean increase and decrease, respectively, and the number of symbols represents slight, moderate, or strong association. The strength of association increases with increasing concentrations of triacylglycerol. 
Table 9. Association of fatty liver with health status in dairy cows.

\begin{tabular}{lll}
\hline Disorder & Association $^{1}$ & Reference \\
\hline Displaced abomasum & +++ & Wada et al., 1995; Rehage et al., 1996 \\
Impaired immunoreactivity & ++ & Wentink et al., 1997; Zerbe et al., 2000 \\
Ketosis & +++ & Gröhn et al., 1987; Veenhuizen et al., 1991 \\
Laminitis & + & Fronk et al., 1980; Rehage et al., 1996 \\
Mastitis & ++ & Morrow et al., 1979 \\
Metritis & ++ & Haraszti et al., 1982; Heinonen et al., 1987 \\
Milk fever & + & Higgins and Anderson, 1983; Gröhn et al., 1987 \\
Retained placenta & + & Haraszti et al., 1982; Heinonen et al., 1987 \\
\hline
\end{tabular}

${ }^{1}$ The number of + represents slight, moderate, or strong detrimental association of fatty liver. The strength of association increases with increasing concentrations of triacylglycerol.

Milk production, health status, and reproductive performance of dairy cows with fatty liver can be decreased for weeks after concentrations of liver TAG decrease back to baseline concentrations (Veenhuizen et al., 1991; Breukink and Wensing, 1997), which suggests that fatty liver is associated with long term histological, metabolic, and hormonal changes. Accumulation of TAG in liver reverses slowly (Veenhuizen et al., 1991) and probably has only minor long term negative associations with the liver itself because liver cells can regenerate within days. The detrimental associations of fatty liver with other tissues, however, are probably longer term and less reversible.

\section{Immunological Pathology of Fatty Liver}

The incidence of fatty liver is strongly associated with the incidence of other metabolic disorders, especially ketosis and displaced abomasum (Table 9) because these metabolic disorders have in common that the cows either are or will be in a severe negative energy balance. Accumulation of liver lipids in cows also is associated with increased length and severity of infectious diseases such as mastitis (Hill et al., 1985) and metritis (Haraszti et al., 1982). The incidence and severity of infectious diseases are increased somewhat in the peripartal period, even without the presence of fatty liver (Goff and Horst, 1997), because immune functions are suppressed and concentrations of proinflammatory cytokines such as tumor necrosis factor-alpha (TNF $\boldsymbol{\alpha}$ ) are increased (Ametaj et al., 2002).

Different aspects of the immune response are suppressed in cows with fatty liver (Breukink and Wensing, 1997; Suriyasathaporn et al., 2000). The lower cellular cytotoxicity and reactive oxygen species generation of polymorphonuclear cells in blood suggest a decreased capacity for phagocytosis by polymorphonuclear cells and macrophages in cows with fatty liver (Zerbe et al., 2000). The lower IgG concentrations after tetanus toxoid immunization (Wentink et al., 1997) and the lower interferon production in blood leukocytes (Szuster-Cie- sielska et al., 1995) suggest that cows with fatty liver have decreased capacity to release some of the inflammatory mediators. The lower concentrations of leukocytes, lymphocytes, eosinophils, monocytes, and mature neutrophils in blood (Morrow et al., 1979; Reid et al., 1986), the decreased lymphoproliferative response after tetanus toxoid immunization (Wentink et al., 1997), and the lower number of membrane antigens on the surface of polymorphonuclear cells (Zerbe et al., 2000) suggest a decreased capacity of blood leukocytes to migrate into the infected mammary gland.

The decreased clearance of endotoxins (Breukink and Wensing, 1997) and the increased concentrations of the acute phase proteins haptoglobulin and serum amyloid A, which are synthesized in the liver (Ametaj et al., 2002; Katoh, 2002), suggest that accumulation of liver lipids can affect the immune response directly by altering the ability of the liver to synthesize and degrade compounds involved in the immune response (Shi et al., 2001; Katoh, 2002). It is more likely, however, that liver lipid accumulation is associated indirectly with a decreased immune response by its association with changes in metabolic hormones, metabolites, and compounds, which affect immune functions (Breukink and Wensing, 1997; Suriyasathaporn et al., 2000). Elevated concentrations of BHBA and NEFA have compromised the immune response in vitro (Suriyasathaporn et al., 2000), and IGF-I stimulates neutrophil function (Zhao et al., 1993). Because lipoproteins protect various species of nonruminants against endotoxin-induced toxicity (Harris et al., 2000), it can be assumed that decreased lipoprotein concentrations in blood also are detrimental to the immune response.

Conversely, inflammatory responses could be part of the etiology of fatty liver and other periparturient disorders (Ametaj et al., 2002; Fürll and Leidel, 2002; Katoh, 2002). Liver lipid accumulation can be preceded by increased concentrations of the proinflammatory cytokine $\mathrm{TNF} \alpha$ (Ametaj et al., 2002), which increase insulin resistance and plasma concentrations of haptoglobulin and serum amyloid A (Katoh, 2002). Haptoglobin binds 
Table 10. Association of fatty liver with reproductive performance in dairy cows.

\begin{tabular}{lll}
\hline Parameter & Association & \\
\hline First ovarian activity & ++ & Reference \\
First ovulation & + & Reid et al., 1983; Rukkwamsuk et al., 1999c \\
First estrus & + & Reid et al., 1983 \\
First insemination & + & Paulová et al., 1990; Jorritsma et al., 2000 \\
Days open & ++ & Reid et al., 1983 \\
Pregnancy rate & ++ & Heinonen et al., 1987; Paulová et al., 1990 \\
Services/cow & + & Haraszti et al., 1982; Jorritsma et al., 2000 \\
\hline
\end{tabular}

${ }^{1}$ The number of + represents slight, moderate, or strong detrimental association of fatty liver. The strength of association increases with increasing concentrations of triacylglycerol.

to apoprotein A-I, which could interfere with the functions of apoprotein A-I in HDL receptor binding and in the exchange of cholesteryl esters in steroidogenic tissues (Katoh, 2002).

\section{Reproductive Pathology and Fatty Liver}

Cows with fatty liver have decreased reproductive performance (Table 10) because follicular development starts in the early postpartal period (Breukink and Wensing, 1997). Decreased reproductive performance can be explained partly by delayed uterine involution (Higgins and Anderson, 1983). The delayed involution can be explained by an increased incidence, length, and severity of endometritis (Haraszti et al., 1982; Heinonen et al., 1987; Sheldon et al., 2002), which can be caused by a delayed and decreased immune response in the uterus (Zerbe et al., 2000). Delayed initiation of ovarian activity (Table 10) can be explained partly by decreased and delayed synthesis of steroidogenic hormones, i.e., progesterone and luteinizing hormone (Zhou et al., 1997).

Another reason for the delayed initiation of ovarian activity is a severe negative energy balance (Herdt, 1991). Additionally, decreased concentrations of IGF-I, insulin, and lipoproteins (Herdt, 1991) and elevated concentrations of ammonia, NEFA, and urea can impair normal ovarian function (Comin et al., 2002; Jorritsma et al., 2003). Decreased pregnancy rates in cows with fatty liver (Table 10) can be explained by decreased numbers of oocytes that survive during early embryonic development (Wensing et al., 1997). The much lower survival rates of oocytes collected at d 81 to 120 postpartum from cows with fatty liver (Wensing et al., 1997) suggest that the negative associations of fatty liver with reproductive performance persist until midlactation.

\section{ETIOLOGY OF FATTY LIVER}

Fatty liver develops primarily in the metabolically and physiologically challenging periparturient period because of insufficient nutrient uptake and hormonal changes and is associated with greater incidence of diseases, infections, and inflammations. Fatty liver has been observed also in late pregnancy when cows were fed for $5 \mathrm{~d}$ with straw only (Gerloff and Herdt, 1984). Risk factors for fatty liver (Table 11) can be grouped into 3 categories: nutritional, managerial, and genetic.

\section{Nutritional Risk Factors for Fatty Liver}

Nutritional risk factors are related to increased lipolysis of adipose tissue or specific nutrients, hormones, or toxins that alter metabolism in the liver (Herdt, 2000). The primary nutritional risk factor for fatty liver is obesity. In obese cows (BCS $\geq 4.0$ ), lipolysis of adipose tissue is increased more during metabolically and immunologically challenging situations, such as the peripartal period, than it is in cows with normal BCS (Rukkwamsuk et al., 1998). Obese cows have a greater decrease in feed intake in such situations and, therefore, have a more severe negative energy balance (Stockdale, 2001).

The more severe negative energy balance and decreased feed intake of obese cows in the peripartal period could be explained by the fact that increased adipose mass is associated with increased adipocyte cell size and increased adipose sensitivity to glucocorticoids and decreased sensitivity to BHBA, glucose, and insulin (Rukkwamsuk et al., 1998; Herdt, 2000). Bovine adipocytes secrete hormone-like compounds such as leptin (Chelikani et al., 2003) and most likely the proinflammatory cytokine, $\mathrm{TNF} \alpha$ (Ohtsuka et al., 2001), although the expression of $\mathrm{TNF} \alpha$ in bovine adipose tissue has not been confirmed. Both compounds decrease feed intake and insulin sensitivity and increase hepatic lipogenesis, catabolism, and inflammation (Drackley, 1999; Ohtsuka et al., 2001; Kushibiki et al., 2003). Obesity does not necessarily cause fatty liver, especially when cows stay healthy or adapt their feed intake to their milk production (Smith et al., 1997).

The effects of prepartal diets on the development of fatty liver are inconsistent (Hippen et al., 1999; Gerloff, 2000; Bobe et al., 2003). Possible reasons for the vari- 
Table 11. Risk factors for fatty liver in lactating dairy cows.

\begin{tabular}{lll}
\hline Risk factor & Effect ${ }^{1}$ & Reference \\
\hline Prepartum: & & Wensing et al., 1997 \\
Obesity (BCS $\geq 4.0)$ & ++ & Gerloff and Herdt, 1984 \\
Severe feed restriction & +++ & Wensing et al., 1997 \\
Feeding excess energy & ++ & Stöber and Scholz, 1991 \\
Long calving interval & + & \\
Postpartum (especially around calving and when cows are obese): & ++ & Katoh, 2002 \\
Diseases and infections & +++ Brumby et al., 1975; Fürll et al., 1993 \\
Fasting & ++ & Staufenbiel et al., 1992; Drackley, 1999 \\
Feed restriction & + & Stöber and Scholz, 1991 \\
Ketogenic diets & + & Stöber and Scholz, 1991; Gerloff, 2000 \\
Sudden feed changes & + & + \\
\hline
\end{tabular}

${ }^{1}$ The number of + represents slight, moderate, and strong risk factors for fatty liver.

able results are differences in BCS prior to dietary treatment, length and time of the prepartal dietary treatment period, differences in composition of the postpartal diet, and differences in other risk factors for fatty liver (Smith et al., 1997; Bobe et al., 2003). Therefore, studies that investigate the effects of BCS, prepartal diet, and postpartal diet in a factorial design are warranted.

The effects of postpartal diets on the development of fatty liver vary and are affected by similar factors, as are the effects of prepartal diets on fatty liver development (Gerloff, 2000). Sudden dietary changes and high concentrate diets increase the risk for ruminal acidosis and bacterial endotoxemia (Goff and Horst, 1997). Both of these diseases are involved in the etiology of fatty liver (Nikov et al., 1981; Fürll and Leidel, 2002). Postpartal diets containing high concentrations of protein can increase the risk for fatty liver (Murondoti et al., 2002), which could be caused by a more severe negative energy balance and increased concentrations of ammonia in blood, which are toxic at high concentrations. Further studies are needed to evaluate the effects of prepartal and postpartal diets and their interactions with each other, BCS, and health status of cows on development of fatty liver before definitive recommendations can be given.

Feed restriction by 30 to $50 \%$ and fasting for 4 to 6 $\mathrm{d}$ prepartum or postpartum can induce fatty liver (Table 11). The effectiveness of inducing fatty liver by feed restriction depends on the propensity of the cows to go into severe negative energy balance, which is greatest directly after calving (Drackley et al., 1992; Drackley, 1999). Feeding only straw for $5 \mathrm{~d}$ to decrease BCS in obese cows in late pregnancy has been observed to induce prepartal fatty liver, an abortion, and a high mortality rate (Gerloff and Herdt, 1984). Restricting feed by $20 \%$ decreased liver TAG concentration (Douglas et al., 1998; Drackley, 1999), but a follow up study by the same investigators could not confirm the results (Douglas et al., 2002).
Fatty liver can be caused by specific nutrients, hormones, or toxins that alter metabolism in the liver. To increase the likelihood of inducing fatty liver, 1,3butanediol has been used together with feed restriction to induce experimental fatty liver and ketosis in cows, because 1,3-butanediol increases plasma BHBA concentrations (Drackley et al., 1992). The combination of 1,3-butanediol with feed restriction has a higher success rate for inducing fatty liver than does either treatment alone (Drackley et al., 1992); however, the fatty liver induction protocol is more successful in cows that are naturally susceptible to fatty liver (Smith et al., 1997; Hippen et al., 1999). Overfeeding a ration in a prolonged dry period ( 2 to $3 \mathrm{mo}$ ) and a short period of starvation ( 6 to $8 \mathrm{~h}$ ) after the onset of calving has been the most promising fatty liver induction protocol (Wentink et al., 1997; Rukkwamsuk et al., 1998, 1999c). The authors, however, did not report the range of liver TAG concentrations in the control and fatty liver groups, and thus the success rate of this model cannot be determined.

Fasting for 4 to $6 \mathrm{~d}$ combined with injections of either estrogen or dexamethasone or administration of 225 $\mathrm{mg}$ dosages of ethionine, a methionine analog, at a 1-wk interval, have the highest success rate for consistently inducing fatty liver in cows independent of their stage of lactation (Grummer, 1993; Katoh, 2002). Feed restriction and dexamethasone increases lipolysis in adipose tissue (Katoh, 2002), and estrogen increases hepatic lipogenesis (Grummer, 1993). Ethionine inhibits ATP-dependent hepatic synthesis of proteins and phospholipids by decreasing ATP concentrations (Katoh, 2002). The BCS of cows was not reported for any of these trials (Grummer, 1993; Katoh, 2002). Therefore, it remains questionable whether thin cows $(\mathrm{BCS} \leq 2.5)$ can develop fatty liver because excessive NEFA cannot be mobilized from adipose tissue.

Deficiencies of AA and water-soluble vitamins induce fatty liver in nonruminants but apparently not in dairy cows (Grummer, 1993). Bacteria present in the rumen 
usually supply cows with sufficient essential AA, vitamins, and antioxidants, but deficiencies can occur during feed changes, when spoiled feed is fed, or during the peripartal periods because of the higher requirements (Stöber and Scholz, 1991). Therefore, we conclude that under certain conditions, AA and vitamin deficiencies play roles in the etiology of fatty liver. It cannot be excluded, however, that the development of fatty liver was elicited by an energy deficit rather than by an AA and vitamin deficiency, because feed changes, spoiled feed, and the periparturient period are associated closely with negative energy balance.

\section{Management Risk Factors for Fatty Liver}

Management factors that are related to nutrition and health status also can influence the incidence of fatty liver. Poor quality feeds, such as silage with elevated butyrate concentration, increase the incidence of fatty liver by increasing BHBA production and decreasing feed intake (Stöber and Scholz, 1991). Abrupt feed changes or feeding high-concentrate diets can cause rumen acidosis (Goff and Horst, 1997), which occurs frequently in the peripartal period and is involved in the etiology of fatty liver (Nikov et al., 1981), because acidosis increases ketogenesis and concentrations of endotoxins and proinflammatory cytokines (Fürll and Leidel, 2002; Kushibiki et al., 2003). Therefore, administration of rumen fluid from healthy cows often is recommended for cows with severe fatty liver to prevent rumen acidosis (Stöber and Scholz, 1991).

A greater proportion of older cows have fatty liver (Reid, 1980; Woltow et al., 1991). This increase might be related to excessive adipose tissue at calving (Jorritsma et al., 2000), higher milk production, longer calving intervals (Stöber and Scholz, 1991), weaker immune responses (Mehrzad et al., 2002), or a lower antioxidant status (Gilbert et al., 1993), all of which are independent risk factors for fatty liver.

Other risk factors for fatty liver are inadequate space or lack of exercise for periparturient cows, poor sanitary conditions, high environmental temperatures, high humidity, and poor air circulation (Stöber and Scholz, 1991; Gerloff, 2000). All such factors can cause release of catecholamines that induce release of NEFA from adipose tissue, decrease feed intake, and increase risk for infections during the peripartal period when cows are more susceptible to infections (Goff and Horst, 1997). Diseases, particularly displaced abomasum, locomotive disorders, toxic mastitis, metritis, milk fever, and retained placenta decrease feed intake, increase nutrient requirements, and cause inflammatory responses that increase lipolysis in adipose tissue, thereby increasing lipid infiltration of the liver
(Drackley, 1999). The strength of association of a disease with fatty liver is related strongly to the degree of negative energy balance caused by the disease. Other risk factors that are associated with decreased feed intake and increased lipolysis in adipose tissue include extended pregnancy and dystocia (Herdt, 2000).

\section{Genetic Risk Factors for Fatty Liver}

Genetic factors that increase the probability of fatty liver can include mutations that affect feed intake, lipid metabolism in adipose tissue, or lipid metabolism and secretion in liver. More specifically, mutations that increase lipogenesis in liver and lipolysis in adipose tissue and decrease $\beta$-oxidation and lipid packaging and secretion in the liver are very likely to cause fatty liver. To date, no specific gene has been found in cattle that increases the incidence of fatty liver in the general population.

To our knowledge, there are no heritability estimates for liver TAG or lipids. However, for ketosis and displaced abomasum, which are both associated closely with fatty liver, heritability estimates are between 0.07 and 0.32 for ketosis (Duffield, 2000) and 0.24 for displaced abomasum (Geishauser et al., 1996). Such estimates indicate a possible genetic basis for fatty liver. The variable success of inducing fatty liver by feed restriction combined with administration of 1,3 butanediol indicates also that some cows are more susceptible to fatty liver (Smith et al., 1997; Hippen et al., 1999). One problem with genetic selection against fatty liver would be that many high producing cows develop mild fatty liver in early lactation, because a severe negative energy balance and insulin resistance at the beginning of lactation enables high milk production throughout the lactation (Herdt, 2000). Development of physiological tests that examine the susceptibility of cows to fatty liver could help determine the genetic basis of fatty liver independent of milk production. A similar approach has been used to examine the genetic basis of immune function (Tempelman et al., 2002).

\section{PREVENTION OF FATTY LIVER}

The goal of preventatives for fatty liver (Table 12) is to decrease or, even better, to eliminate most of the potential risk factors for fatty liver (Table 11). There are several general management practices that can help prevent fatty liver. Feeding cows a balanced ration according to their dietary requirements in the periparturient period is recommended. Treating cows immediately and aggressively in the periparturient period for infectious and metabolic disorders is recommended. A clean stall that is ventilated well with fresh air, sufficient 
Table 12. Preventatives and treatments for different levels of fatty liver or ketosis in lactating dairy cows.

\begin{tabular}{|c|c|c|}
\hline Preventative/treatment & Effect $^{1}$ & Reference \\
\hline Ammonium propionate & + & Fürll and Leidel, 2002 \\
\hline Calcium propionate & + & Goff et al., 1996 \\
\hline Glucagon & ++ & Nafikov et al., 2002 \\
\hline Glucocorticoids & ++ & Fürll et al., 1993 \\
\hline Glycerol & $+/ 0$ & DeFrain et al., 2003 \\
\hline Monensin & ++ & Duffield et al., 2003 \\
\hline Niacin & $+/ 0$ & Dufva et al., $1983^{2}$ \\
\hline Propylene glycol (bolus dose) & ++ & Studer et al., 1993; Christensen et al., 1997; Pickett et al., 2003 \\
\hline Sodium borate & + & Basoglu et al., 2002 \\
\hline \multicolumn{3}{|c|}{ Treatment for mild and moderate fatty liver or ketosis: } \\
\hline Glucagon & $+/ 0$ & Bobe et al., 2003 \\
\hline Magnesium propionate & $+/ 0$ & Hamada et al., 1982 \\
\hline Nicotinic acid (bolus dose) & $+/ 0$ & Waterman et al., 1972; Nurmio et al., 1974 \\
\hline Potassium chlorate & + & Gruchy et al., 1963 \\
\hline Propylene glycol & ++ & Schultz, 1952; Hamada et al., 1982 \\
\hline Sodium propionate & + & Schulz, 1952; Gruchy et al., 1963 \\
\hline Xylitol & + & Hamada et al., 1982; Sakai et al., 1996 \\
\hline \multicolumn{3}{|c|}{ Treatments for severe fatty liver or ketosis: } \\
\hline Glucagon (continuous infusion) & ++ & Hippen et al., 1999 \\
\hline Glucose (continuous infusion) & ++ & Stöber and Scholz, 1991 \\
\hline Glucose + glucocorticoids & +++ & Jonsgård et al., 1974; Mudron et al., 1999 \\
\hline Glucose + insulin & ++ & Stöber and Scholz, 1991; Sakai et al., 1993 \\
\hline Propylene glycol + glucocorticoids & $+/ 0$ & Kauppinen and Gröhn, 1984 \\
\hline
\end{tabular}

${ }^{1}$ The number of + indicates slight, moderate, or strong effectiveness as preventative or treatment for fatty liver; 0 indicates no beneficial effect.

${ }^{2}$ Results are dosage dependent.

${ }^{3}$ Only study with positive results.

space and exercise, and fresh, high quality feed are all important to prevent diseases.

The primary approaches to prevent fatty liver are to counteract oxidative or cytotoxic damage to the liver, bacterial endotoxemia, and ruminal acidosis and, most importantly, to improve the metabolic state of cows in the peripartal period by supplying an extra source of blood glucose and by decreasing mobilization of NEFA from adipose tissue.

The glucose supply can be increased by injections of hormones. Possible options are glucagon, insulin, ACTH, glucocorticoids, and growth hormone. Subcutaneous injections of glucagon $(15 \mathrm{mg} / \mathrm{d}$ for $14 \mathrm{~d}$; Nafikov et al., 2002) and intramuscular injections of glucocorticoids (200 mg/d of prednisolone; Fürll et al., 1993) have been demonstrated to be successful preventatives of fatty liver. The primary beneficial effect of glucocorticoids, ACTH, and glucagon is to increase gluconeogenesis in the liver (Table 13), which increases concentrations of plasma glucose. Slow-release insulin at dosages of $0.14 \mathrm{IU} / \mathrm{kg}$ BW was also effective in preventing TAG accumulation in the liver. Higher dosages of insulin ( 0.29 and $0.43 \mathrm{IU} / \mathrm{kg} \mathrm{BW})$, however, can result in hypoglycemic shock (Hayirli et al., 2002). Neither glucagon nor insulin are approved for use in lactating dairy cows in the United States. Growth hormone had no beneficial effect (Fetrow et al., 1999), which can be explained by the fact that growth hormone is less effective in increasing IGF-I during early lactation (Vicini et al., 1991).

Oral drenches of $1 \mathrm{~L} / \mathrm{d}$ of propylene glycol for the last $10 \mathrm{~d}$ prepartum have been demonstrated to prevent fatty liver and ketosis by increasing plasma glucose and insulin concentrations and decreasing plasma BHBA and NEFA concentrations (Studer et al., 1993; Duffield, 2000). A recent study, however, could not confirm a preventive effect on fatty liver when oral drenches of $0.5 \mathrm{~L} / \mathrm{d}$ of propylene glycol for the first $3 \mathrm{~d}$ postpartum were used (Pickett et al., 2003). The effectiveness of propylene glycol to increase plasma glucose concentrations depends on the dosage and the mode of administration, with stronger increases occurring in cows given higher dosages and when administered by oral 
Table 13. Metabolic functions of hormones in comparison to different categories of fatty liver. ${ }^{1}$

\begin{tabular}{|c|c|c|c|c|c|c|}
\hline Metabolic function & $\begin{array}{l}\text { Moderate } \\
\text { fatty liver }\end{array}$ & $\begin{array}{l}\text { Severe } \\
\text { fatty liver }\end{array}$ & Glucagon & Insulin & $\begin{array}{l}\text { ACTH/ } \\
\text { glucocorticoids }\end{array}$ & $\begin{array}{l}\text { Growth } \\
\text { hormone }\end{array}$ \\
\hline \multicolumn{7}{|l|}{ Hepatocytes: } \\
\hline Gluconeogenesis & $0^{2}$ & - & + & - & + & + \\
\hline Glycogenesis & - & - & - & + & + & 0 \\
\hline Glycogenolysis & + & 0 & + & - & 0 & 0 \\
\hline Ketogenesis & + & - & + & - & + & + \\
\hline Lipogenesis & + & + & - & + & 0 & 0 \\
\hline$\beta$-Oxidation & + & - & + & - & + & + \\
\hline Protein synthesis & - & - & - & + & - & + \\
\hline Proteolysis & \pm & + & \pm & - & 0 & 0 \\
\hline VLDL3 secretion & + & - & \pm & \pm & + & + \\
\hline \multicolumn{7}{|l|}{ Adipocytes: } \\
\hline Glucose uptake & 0 & 0 & \pm & + & 0 & 0 \\
\hline Lipogenesis & 0 & 0 & \pm & + & 0 & 0 \\
\hline Lipolysis & + & + & \pm & - & + & + \\
\hline Lipoprotein lipolysis & 0 & 0 & \pm & + & 0 & 0 \\
\hline
\end{tabular}

${ }^{1}$ Adapted from Engelking (2000).

${ }^{2}$ The symbols,,+- \pm , and 0 mean, respectively, increase, decrease, variable, and no effect.

${ }^{3}$ Very-low-density lipoprotein.

drenches (Pehrson, 1972; Christensen et al., 1997). Oral drenches, however, are less practical for on-farm use than is administration to the diet. Differences in responses are related partly to changes in ruminal fermentation and VFA production in favor of propionate (Pehrson, 1972; Schäfer et al., 1975; Christensen et al., 1997). Propylene glycol decreases VFA concentrations in the rumen, particularly concentrations of acetate and butyrate, indicating that higher concentrations of propylene glycol might be toxic for some ruminal bacteria species (Pehrson, 1972).

Nontoxic dosages of sodium borate (Basoglu et al., 2002) have prevented fatty liver but are less researched. The improved hematological indices suggest that sodium borate either improves immune function or decreases infections (Basoglu et al., 2002).

Approaches that were mostly unsuccessful in preventing fatty liver include feeding a) supplemental fat prepartum, b) niacin or nicotinic acid, or c) compounds involved in lipid metabolism. Feeding supplemental fat prepartum prevented TAG accumulation in the liver (Grum et al., 1996); however, a follow-up study by the same investigators did not confirm the positive effect of their initial study (Douglas et al., 1998, 2002). Similarly, after encouraging results in initial studies, oral administration of niacin or nicotinic acid failed to prevent ketosis and fatty liver in more recent studies (Minor et al., 1998). The proposed mode of action was that supraphysiological concentrations of niacin decrease NEFA mobilization from adipose tissue; however, achieving supraphysiological plasma concentrations by oral administration is difficult, because niacin is degraded in the rumen (Dufva et al., 1983).
Dietary supplementation of compounds involved in lipoprotein synthesis and secretion were usually unsuccessful in preventing fatty liver and ketosis (Gerloff et al., 1986b; Bauchart et al., 1998; Piepenbrink and Overton, 2003). This approach is based on the assumption that deficiencies of compounds involved in lipoprotein synthesis and secretion, such as carnitine, choline, cyanocobalamin, inositol, lysine, and methionine, can cause fatty liver in dairy cows just as they do in nonruminants (Bauchart et al., 1998). The failure to prevent fatty liver indicates that cows are either not usually deficient in those compounds, that compounds are quickly degraded in rumen, or that lipoprotein synthesis in ruminants cannot be changed easily.

Promising alternatives to the currently reported fatty liver preventatives are dietary administration of monensin and glucose precursors such as glycerol and propionate salts. Administration of ammonium and calcium propionate orally and administration of $1 \mathrm{~kg} / \mathrm{d}$ of glycerol to the diet in the periparturient period decreased plasma BHBA and NEFA concentrations, respectively (Goff et al., 1996; Fürll and Leidel, 2002; DeFrain et al., 2003). Feeding monensin during the last month before parturition has prevented ketosis (Duffield, 2000; Duffield et al., 2003). The efficacy of monensin, an antibiotic ionophore, to prevent ketosis depends on the BCS of cows; beneficial effects become evident especially in obese cows (Duffield, 2000). One advantage of monensin is that it is available in a controlledrelease form and, therefore, is easy to administer. Monensin is not approved for use in lactating dairy cows in the United States but is approved in several other countries. 
The primary mode of action of monensin is that it improves the glucose supply to cows by changing ruminal fermentation and VFA production in favor of propionate (Duffield et al., 2003). Monensin supplementation also has prevented bacterial infections in nonruminants (Butaye et al., 2003) but is less beneficial in ruminants. Furthermore, monensin in beef cattle that are fed highgrain diets prevents subacute ruminal acidosis, which is associated with decreased DMI; however, similar beneficial effects of monensin could not be confirmed consistently in dairy cows (Mutsvangwa et al., 2002). Dietary administration of monensin and glucose precursors such as glycerol, propionate salts, and propylene glycol would be more time and cost effective than daily oral drenches of propylene glycol and intramuscular injections of glucocorticoids and, therefore, warrant further investigation.

Overall, the effectiveness of compounds to prevent fatty liver depends on factors that differ for each compound. Therefore, the choice of preventative depends on the specific nutrition and management program of the farm. A primary target group for prevention is made up of cows that are at a higher risk of developing fatty liver in the early postparturient period such as cows that are obese or do not eat well, had calving difficulties or twins, have metabolic or infectious diseases, or quickly lose BCS.

\section{TREATMENT OF MILD AND MODERATE FATTY LIVER}

Treatment of fatty liver depends on the extent of lipid infiltration and the etiology. It is important to counteract the deficiencies that caused the initial lipid infiltration. Diagnosis of mild and moderate fatty liver is difficult and rare because affected cows often do not differ from cows with normal liver in milk production and DMI (Gerloff et al., 1986a), and the only way to correctly diagnose the categories of fatty liver is by liver biopsies, which involve minor surgery to penetrate the body cavity. Therefore, development of a noninvasive technique to categorize concentrations of liver TAG is crucial for informed treatment of mild and moderate fatty liver in the field. Ultrasonic techniques show promise for noninvasively categorizing concentrations of liver TAG (Bobe et al., 1999).

There are some general diagnostic markers, however, that can indicate an increased risk for mild or moderate fatty liver and that are related to severe negative energy balance. Cows with moderate and, to a smaller extent, mild fatty liver often have elevated concentrations of urinary ketones (Gröhn et al., 1983). Cows lose much BCS or BW in a short period before and during the time when they develop mild to moderate fatty liver
(Jorritsma et al., 2001). Their DMI is depressed or much lower than required for milk production before and during the time when cows develop mild to moderate fatty liver (Veenhuizen et al., 1991).

Treatment of mild and moderate fatty liver is important because of its association with decreased metabolic functions of the liver and other organs and decreased health status, reproductive performance, and possibly milk production for months after TAG infiltration subsides. Further, such cows have an increased risk of progressing to severe fatty liver (Gerloff et al., 1986a; Veenhuizen et al., 1991).

General management practices that can treat mild and moderate fatty liver are similar to those for prevention of fatty liver. Feed intake should be increased by offering fresh, high quality legume or grass hay (Stöber and Scholz, 1991). Moderate exercise for $1 \mathrm{~h} / \mathrm{d}$ has been recommended to promote oxidation of ketone bodies in muscle (Stöber and Scholz, 1991). Their recommendation is supported by observations of Jonsgård et al. (1974), who reported that ketosis treatment in Norway was least successful in winter when most cows were in tie stalls.

In comparison to preventatives, there are, to our knowledge, only 2 studies (Fürll and Fürll, 1998; Bobe et al., 2003) that determined the efficacy of potential treatments to reverse mild or moderate hepatic lipidosis. Intramuscular injections of $200 \mathrm{mg}$ of prednisolone daily for $5 \mathrm{~d}$ decreased liver TAG concentrations (Fürll and Fürll, 1998). Subcutaneous injections of $15 \mathrm{mg}$ of glucagon daily for $14 \mathrm{~d}$ reversed accumulation of liver TAG in cows older than 3.5 yr (Bobe et al., 2003).

Most studies focus on the treatment of ketosis without determining liver TAG concentrations. Cows with ketosis are treated primarily with multiple subcutaneous or intramuscular injections of glucocorticoids (10 to $30 \mathrm{mg}$ dexamethasone, 2 to $5 \mathrm{mg}$ flumethasone, or 100 to $200 \mathrm{mg}$ prednisolone; Stöber and Scholz, 1991), with glucose precursors that are administered orally or intravenously, or a combination of both (Table 12). Potassium and sodium chlorates, which are modifiers of ruminal fermentation, have been used for ketosis treatment but are used rarely today (Burns, 1963; Gruchy et al., 1963).

Glucocorticoids differ in the speed and duration of their effectiveness in increasing blood glucose concentrations. Nonesterified glucocorticoids cause a faster but shorter response than do esterified glucocorticoids. Therefore, a combination of both esterified and nonesterified glucocorticoids is recommended (Stöckl et al., 1969). Glucocorticoids can be replaced by ACTH when the adrenal gland is functioning adequately (Shaw, 1956), but it is used rarely. The primary beneficial effect of glucocorticoids, ACTH, and glucagon as treatments 
of fatty liver is to increase gluconeogenesis in the liver (Table 13), which increases concentrations of plasma glucose. A disadvantage of these hormones is that they have to be injected repeatedly, which is not very practical for on-farm use. Development of a subcutaneous slow-release implant of glucagon and glucocorticoids is desirable. A concern for the use of glucocorticoids and glucagon is that they might increase NEFA release from adipose tissue and thereby aggravate ketosis (Hippen et al., 1999). To prevent a potential release of NEFA, a combination of glucocorticoids, nicotinic acid, and dexamethasone-21-iso-nicotinic acid is used (Pehrson, 1972; Fürll and Leidel, 2002).

Recent research, however, questions whether glucocorticoids and glucagon are lipolytic in cows in the peripartal period and rather suggests that glucocorticoids and glucagon decrease lipogenesis in adipose tissue, which is very low during the peripartal period (Fürll and Fürll, 1998; Hippen et al., 1999). A disadvantage of glucocorticoids is that they affect the immune response; however, this was not true for all studies (Fürll and Fürll, 1998; Hoeben et al., 1999; Tempelman et al., 2002). Therefore, studies are warranted to determine how glucocorticoid treatment affects cows with infections and fatty liver that are treated with antibiotics (Stöber and Scholz, 1991). Glucocorticoids can cause hyperglycemia (Shaw, 1956; Fürll et al., 1993). Furthermore, glucocorticoids alone are less effective in treating ketosis than in combination with glucose infusions (Shpigel et al., 1996), and glucocorticoids increase blood glucose and liver glycogen concentrations slower (Burns, 1963) and are less effective in treating ketosis (Gruchy et al., 1963) than is glycerol. In comparison to glucocorticoids and ACTH, glucagon is more liver specific, less lipolytic, and more glycogenolytic, gluconeogenic, and insulinotropic (Table 13; Bassett, 1971).

Oral administrations of $1 \mathrm{~kg} / \mathrm{d}$ of glycerol, $1 \mathrm{~L} / \mathrm{d}$ of propylene glycol, or $100 \mathrm{~g} / \mathrm{d}$ of sodium propionate have been effectively used for treatment of ketosis (Table 12). Of the 3 glucose precursors, glycerol is the most palatable and most effective in increasing glucose concentrations for an extended time; however, glucose concentrations increase slower, and greater amounts of glycerol need to be administered to achieve similar increases in plasma glucose concentrations (Johnson, 1954; Gruchy et al., 1963; Pehrson, 1972). None of the above mentioned studies compared the efficacy of glycerol, propionate salts, and propylene glycol at the same dosage on a molar or weight basis. Still, most reviews noted that propylene glycol was more beneficial for treatment of ketosis than was sodium propionate or glycerol (Schäfer et al., 1975). Therefore, there is a definite need to compare the potency of glycerol, propionate salts, and propylene glycol to prevent and treat fatty liver before specific recommendations can be made.

A disadvantage of propylene glycol, glycerol, and sodium propionate is that they decrease VFA concentrations in the rumen, in particular concentrations of acetate and butyrate (Pehrson, 1972; Schäfer et al., 1975; Christensen et al., 1997). Additionally, propionate decreases feed intake in most but not all studies (Oba and Allen, 2003). Regarding toxicity, a 1.8-kg dose of propylene glycol via a rumen tube or 2 to $3 \mathrm{~L}$ of glycerol administered orally can be neurotoxic (Johnson, 1954). The dosage that causes drowsiness varies among animals, which suggests that the amount absorbed varies between animals (Johnson, 1954). Higher dosages of sodium propionate $(0.5 \mathrm{~kg})$ can cause diarrhea and higher water intake because sodium ions alter electrolyte concentrations in blood and increase ruminal $\mathrm{pH}$, which as a positive side effect can decrease ruminal acidosis (Shaw, 1956; Pehrson, 1972; Oba and Allen, 2003). Therefore, the daily dosage of sodium propionate to treat ketosis and fatty liver should be increased slowly over days of administration (Schultz, 1952).

Combinations of sodium propionate with glycerol or propylene glycol may be more effective than either alone because sodium propionate increases blood glucose faster than does glycerol or propylene glycol. A combination of sodium propionate (300 g) with glycerol (500 g) caused hyperglycemia and severe diarrhea in ketotic cows, which can be explained by the high concentrations of glucose precursor used. A later study with a combination of $75 \mathrm{~g}$ of sodium propionate, $125 \mathrm{~g}$ of glycerol, and $100 \mathrm{~g}$ of propylene glycerol proved to be effective for treatment of ketosis (Pehrson, 1972).

Calcium and magnesium propionate have been used for treatment of ketosis (Hamada et al., 1982; Goff et al., 1996). They are less soluble, increase blood glucose concentrations slower, and have less effect on rumen $\mathrm{pH}$ and concentrations of electrolytes in blood than does sodium propionate (Shaw, 1956). Other glucose precursors are amonium lactate, calcium lactate, magnesium propionate, sodium lactate, sodium propionate, and tripropionin, which is the glycerol ester of propionic acid (Johnson, 1954; Shaw, 1956), but they are used rarely today. For soluble carbohydrates to be effective by oral administration, large dosages ( $3 \mathrm{~kg} / \mathrm{d}$ glucose) have to be used, because they are readily fermented in the rumen to VFA, which causes smaller increases of plasma glucose concentrations (Shaw et al., 1942).

In comparison to glucocorticoids, glycerol, and sodium propionate, the efficacy of intravenous infusions of glucose to prevent ketosis is numerically lower (Gruchy et al., 1963). One reason is that blood glucose is increased for only 80 to $100 \mathrm{~min}$ after infusion is stopped (Shaw, 1956). Furthermore, a significant number of 
cows do not react to glucose infusions, which suggests that the glucose infusions either did not induce pancreatic insulin secretion or that cows developed insulin resistance (Ohtsuka et al., 2001). Instead of glucose, intravenous administrations of $250 \mathrm{~g}$ of carbohydrates such as fructose, mixtures of glucose and fructose, and xylitol have been used (Table 12).

Xylitol is the most promising carbohydrate for successful treatment, because it increases insulin concentrations more and decreases concentrations of plasma ketones more than does glucose (Hamada et al., 1982; Sakai et al., 1996). Invert sugar, which is created by invertase treatment of sucrose and is a mixture of glucose and fructose, probably is the next best alternative for treatment because invert sugar is less inhibitory to gluconeogenesis and causes lower glucose losses via urine than does glucose (Kouider et al., 1978). Fructose is the least promising treatment, because intravenous administration of glucose increases concentrations of both glucose and insulin more and longer than does fructose (Kouider et al., 1978). The major disadvantage of intravenous infusions is that they are impractical for on-farm use.

In summary, the scarcity of studies that have determined the efficacy of treatments for mild and moderate fatty liver demonstrates that additional studies to confirm and compare the effectiveness of different hormones and carbohydrates alone and in combination are needed.

\section{TREATMENT OF SEVERE FATTY LIVER}

There are 2 forms of severe fatty liver. Nonencephalopathic severe fatty liver usually is characterized by low feed intake and elevated concentrations of urinary ketones. The more extreme form of severe fatty liver is hepatic encephalopathy, which is characterized additionally by depressed consciousness, ataxia, somnolency, and coma. It often is lethal despite intensive treatment. Nonencephalopathic severe fatty liver usually is not lethal; the cows, however, never regain full health and productivity. Even if they eventually become pregnant, they often develop severe fatty liver again in the following lactation and are culled early in that lactation. Many veterinarians, therefore, recommend immediate culling of cows with severe fatty liver. Effective treatment of cows with severe fatty liver has to be aggressive and long term. The recovery period can last several weeks, because these cows tend to relapse and easily go off feed again.

Cows are diagnosed rarely as having severe fatty liver, because diagnosis requires minor surgery and a liver biopsy. This requirement could explain why there is only one study to our knowledge (Hippen et al., 1999) that specifically tested the efficacy of a treatment of severe fatty liver. Hippen et al. (1999) demonstrated that continuous intravenous infusions of glucagon for $14 \mathrm{~d}$ successfully treats nonencephalopathic severe fatty liver. The disadvantage is that continuous, intravenous infusions are not practical for on-farm use, and glucagon has not been approved for use in lactating cows.

Most studies have focused on testing the efficacy of treatments in severely ketotic cows and did not determine liver TAG concentrations. Typical treatments for severe ketosis are continuous intravenous infusions of glucose for 2 to $3 \mathrm{~d}$ at 0.5 to $1 \mathrm{~kg} / \mathrm{d}$ (Stöber and Scholz, 1991) and infusions of glucose combined with glucocorticoids or insulin (Table 12). The combination treatments are preferred by most veterinarians because glucose infusion supplies glucose quickly and glucocorticoids supply longer term glucose, whereas insulin helps with the uptake of glucose by peripheral tissues (Table 13). Chloral hydrate (2,2,2-trichloro-1,1-ethanediol) is the oldest treatment of severe ketosis and was used primarily in cases of nervous ketosis because it is an anesthetic, but it is rarely used today (Shaw, 1956). Chloral hydrate is a very potent rumen modifier that is also a potent bacteriocide (Quaghebeur and $\mathrm{Oy}$ aert, 1971).

Using glucose infusions in bolus dosage is a less successful treatment of ketosis (Shaw, 1956; Gruchy et al., 1963), because blood glucose is increased only for 80 to $100 \mathrm{~min}$ after the infusion stops (Shaw, 1956). Injections of dexamethasone with oral administration of propylene glycol is a less effective treatment than combinations of glucose infusions and dexamethasone and dexamethasone alone (Kauppinen and Gröhn, 1984). The addition of glucose precursors to the diet is not recommended, because the DMI is often not sufficient and varies between days.

For treatment of hepatic encephalopathy, intravenous glucose administrations combined with glucocorticoid injections are used (Mudron et al., 1999). For treatment of hepatic encephalopathy in particular, the treatment should be repeated for several days (Mudron et al., 1999). Studies to evaluate the efficacy of different treatment options for severe fatty liver are needed.

\section{CONCLUSIONS}

The objective of this review was to give an overview of the pathology and etiology of fatty liver and then to describe and compare different treatments. Fatty liver is a multifactorial, multifaceted disease that develops when the hepatic uptake of lipids exceeds the oxidation and secretion of lipids by the liver and thereby causes accumulation of TAG in the liver, which is associated 
with decreased metabolic function of the liver. Most of the knowledge about the pathology of fatty liver has been generated in the last $20 \mathrm{yr}$ by quantifying metabolic reactions in hepatocytes and adipocytes by using in vitro techniques and radioactive tracer studies. Future research will probably focus additionally on gene and protein expression in hepatocytes and adipocytes and will attempt to connect data for gene and protein expression with rates of metabolic reactions.

Fatty liver can be categorized into normal liver and mild, moderate, or severe fatty liver; the latter can be further subdivided into nonencephalopathic severe fatty liver and hepatic encephalopathy. Insufficient or unbalanced dietary intake, obesity, and elevated estrogen concentrations are involved in the etiology of fatty liver, which is associated with dystocia, diseases, infections, and inflammations. The metabolic connections between these risk factors and fatty liver as well as the pathology of mild and moderate fatty liver, however, are less understood than the pathology of severe fatty liver.

One challenge is to have an animal model that consistently develops fatty liver. The most promising procedure to induce postpartum fatty liver consists of a combination of overfeeding in a prolonged dry period and a short period of starvation after the onset of calving. Future studies should focus on the development of a good model to study all aspects of the fatty liver syndrome as well as the etiology of fatty liver and identification of early steps in the development of fatty liver as well as their metabolic effects. Identification of these early steps is also important for development and use of early indicators of fatty liver. Gene-array and proteomic studies offer potential methods to detect those steps and hopefully will help in the development of strategies to prevent fatty liver.

Prevention of fatty liver by supplying cows with sufficient nutrients and a clean and health-promoting environment in the peripartal period is always better than any treatment, because fatty liver is associated with decreased health status and reproductive performance of dairy cows. Hopefully, future research will investigate metabolic links between fatty liver and health status and reproductive performance. Such studies will be very challenging, because multiple organ systems are involved, and their interactions are highly complex. Maintaining good health status and reproductive performance of high producing dairy cows, however, is and will continue to be a primary challenge for dairy research and dairy producers.

Preventatives as well as treatments for fatty liver focus on prevention of excessive lipolysis of adipose tissue, increasing hepatic gluconeogenesis or glucose supply, and increasing glucose uptake of extrahepatic tissues. Many different compounds can promote these metabolic actions. Future research will, therefore, reveal new potential preventatives and treatments of fatty liver to the point that preventatives or treatments for specific etiologies and pathologies of fatty liver are developed. These metabolic actions need to be promoted especially in cows that are obese or do not eat well, had calving difficulties or twins, have metabolic or infectious diseases, or are in severe negative energy balance.

Potential preventatives and treatments were summarized and discussed. Successfully tested preventatives are oral drenches of propylene glycol in the periparturient period or injections of glucocorticoids, glucagon, or low dosages of slow-release insulin in the first days after calving. These choices are not very practical for on-farm use, and insulin and glucagon are not approved for use in lactating dairy cows in the United States. The addition of glucose precursors such as glycerol, propyelene glycol, or propionate salts to the feed in the periparturient period is a more practical solution but has not been tested. The only successfully tested treatments of mild and moderate fatty liver are injections of glucagon or glucocorticoids for several days. Oral drenches of glucose precursors and injections of glucagon or glucocorticoids alone or in combination are promising treatments but need to be tested. Cows with severe fatty liver need a more aggressive and longer term treatment. Continuous intravenous infusions of glucose combined with glucocorticoid or insulin injections or continuous intravenous infusions of glucagon offer the most promising treatment to date. Hopefully, future research will provide new treatment options that are more practical and less labor intensive for on-farm use such as slow-release formulas of hormones. Such treatment options will reduce the problem of fatty liver and its detrimental metabolic effects.

\section{ACKNOWLEDGMENTS}

The research was supported partly by grant number 99-35005-8576 from the US Department of Agriculture and was part of regional research project NC-1009 (formerly NC-185).

\section{REFERENCES}

Acorda, J., H. Yamada, and S. Ghamsari. 1995. Comparative evaluation of hydropic degeneration of the liver in dairy cattle through biochemistry, ultrasonography, and digital analysis. Vet. Radiol. Ultrasound 36:322-326.

Alvarez, C., C. Nelms, V. D'Addio, and B. L. Bass. 1997. The pancreatic duct epithelium in vitro: Bile acid injury and the effect of epidermal growth factor. Surgery 122:476-483.

Ametaj, B. N., B. J. Bradford, G. Bobe, Y. Lu, R. Nafikov, R. N. Sonon, J. W. Young, and D. C. Beitz. 2002. Acute phase response indicates inflammatory conditions may play a role in the pathogenesis of fatty liver in dairy cows. J. Dairy Sci. 85(Suppl. 1):189. (Abstr.) 
Basoglu, A., M. Sevinc, F. M. Birdane, and M. Boydak. 2002. Efficacy of sodium borate in the prevention of fatty liver in dairy cows. J. Vet. Intern. Med. 16:732-735.

Bassett, J. M. 1971. The effects of glucagon on plasma concentrations of insulin, growth hormone, glucose, and free fatty acids in sheep: Comparison with the effects of catecholamines. Aust. J. Biol. Sci. 24:311-320.

Bauchart, D., D. Durand, D. Gruffat, and Y. Chilliard. 1998. Mechanism of liver steatosis in early lactation cows. Effects of hepatoprotector agents. Pages 27-37 in Proc. Cornell Nutr. Con. Feed Manuf., Ithaca, NY.

Bobe, G., B. N. Ametaj, J. W. Young, and D. C. Beitz. 2003. Potential treatment of fatty liver with 14-day subcutaneous injections of glucagon. J. Dairy Sci. 86:3138-3147.

Bobe, G., V. R. Amin, A. R. Hippen, D. E. Wilson, G. L. Lindberg, and J. W. Young. 1999. Non-invasive determination of liver lipid content in dairy cows by digital analyses of ultrasonic images. J. Dairy Sci. 82(Suppl. 1):100. (Abstr.)

Bobowiec, R., J. Filar, J. Marczuk, and U. Kosior. 1997. Periparturient changes in plasma lipoprotein composition of dairy cows. Medycyna Wet. 53:734-738. (In Polish; abstract in English).

Bremmer, D. R., S. J. Bertics, S. A. Besong, and R. R. Grummer. 2000. Changes in hepatic microsomal triglyceride transfer protein and triglyceride in periparturient dairy cattle. J. Dairy Sci. 83:2252-2260.

Breukink, H. J., and T. Wensing. 1997. Pathophysiology of the liver in high yielding dairy cows and its consequences for health and production. Isr. J. Vet. Med. 52:66-72.

Brumby, P. E., M. Anderson, B. Tuckley, J. E. Storry, and K. G. Hibbit. 1975. Lipid metabolism in the cow during starvationinduced ketosis. Biochem. J. 146:609-615.

Burns, K. N. 1963. A comparison of the glucogenic effects of some compounds used in the treatment of ketosis. Vet. Rec. 75:763-768.

Butaye, P., L. A. Devriese, and F. Hasesebrouck. 2003. Antimicrobial growth promoters used in animal feed: Effects of well known antibiotics on gram-positive bacteria. Clin. Microbiol. Rev. 16:175-188.

Cadórniga-Valiño, C., R. R. Grummer, L. E. Armentano, S. S. Donkin, and S. J. Bertics. 1997. Effects of fatty acids and hormones on fatty acid metabolism and gluconeogenesis in bovine hepatocytes. J. Dairy Sci. 80:646-656.

Chelikani, P. K., D. R. Glimm, and J. J. Kennelly. 2003. Short communication: Tissue distribution of leptin and leptin receptor mRNA in the bovine. J. Dairy Sci. 86:2369-2372.

Christensen, J. O., R. R. Grummer, F. F. Rasmussen, and S. J. Bertics. 1997. Effect of method of delivery of propylene glycol on plasma metabolites of feed-restricted cattle. J. Dairy Sci. 80:563-568.

Comin, A., D. Gerin, A. Cappa, V. Marchi, R. Renaville, M. Motta, U. Fazzini, and A. Prandi. 2002. The effect of an acute energy deficit on the hormone profile of dominant follicles in dairy cows. Theriogenology 58:899-910.

de Boer, G., A. Trenkle, and J. W. Young. 1985. Glucagon, insulin, growth hormone and some blood metabolites during energy restriction ketonemia of lactating cows. J. Dairy Sci. 68:326-337.

de Boer, G., A. Trenkle, and J. W. Young. 1986. Secretion and clearance rates of glucagon in dairy cows. J. Dairy Sci. 69:721-733.

DeFrain, J. M., A. R. Hippen, K. F. Kalscheur, and P. W. Jardon. 2003. Feeding glycerol to transition dairy cows; effects on dry matter intake, milk production, and blood metabolites. J. Dairy Sci. 86(Suppl. 1):104. (Abstr.)

Douglas, G. N., J. K. Drackley, T. R. Overton, and H. G. Bateman. 1998. Lipid metabolism and production by Holstein cows fed control or high fat diets at restricted or ad libitum intakes during the dry period. J. Dairy Sci. 81(Suppl. 1):295. (Abstr.)

Douglas, G. N., J. Rehage, A. D. Beaulieu, A. O. Bahaa, and J. K. Drackley. 2002. Peripartal changes in fatty acid profiles of blood, adipose tissue, and liver of dairy cows can be modulated by diet. J. Dairy Sci. 85(Suppl. 1):185. (Abstr.)

Drackley, J. K. 1999. Biology of dairy cows during the transition period: The final frontier? J. Dairy Sci. 82:2259-2273.

Drackley, J. K., M. J. Richard, D. C. Beitz, and J. W. Young. 1992 Metabolic changes in dairy cows with ketonemia in response to feed restriction and dietary 1,3-butanediol. J. Dairy Sci. $75: 1622-1634$

Duffield, T. F. 2000. Subclinical ketosis in lactating dairy cows. Vet. Clin. North Am. Food Anim. Pract. 16:231-253.

Duffield, T. F., S. LeBlanc, R. Bagg, K. E. Leslie, J. Ten Hag, and P. Dick. 2003. Effect of a monensin controlled release capsule on metabolic parameters in transition dairy cows. J. Dairy Sci. 86:1171-1176

Dufva, G. S., E. E. Bartley, A. D. Dayton, and D. O. Riddell. 1983 Effect of niacin supplementation on milk production and ketosis of dairy cattle. J. Dairy Sci. 66:2329-2336.

Engelking, L. R. 2000. Metabolic and Endocrine Physiology. Teton New Media, Jackson, WY.

Fetrow, J. P., J. W. Pankowski, J. L. Vicini, and T. R. Ames. 1999. Use of bovine somatotropin at the time of surgery for left displacement of the abomasum in dairy cows. Minnesota Dairy Practitioners Study Group. JAVMA 214:529-531.

Formigoni, A., M. C. Cornil, A. Prandi, A. Merdenti, A. Rossi, D. Portetelle, and R. Renaville. 1996. Effect of propylene glycol supplementation around parturition on milk yield, reproduction performance, and some hormonal and metabolic characteristics in dairy cows. J. Dairy Res. 63:11-24

Fronk, T. J., L. H. Schultz, and A. R. Hardie. 1980. Effect of dry period overconditioning on subsequent metabolic disorders and performance of dairy cows. J. Dairy Sci. 63:1080-1090.

Fürll, M., and B. Fürll. 1998. Glucocorticoid (prednisolone) effects on various blood, urine and liver parameters in cows in the second post partum week. Tieraerztl. Prax. Ausg. G Grosstiere Nutztiere 26:262-268. (In German; abstract in English).

Fürll, M., H. Kirbach, and B. Knobloch. 1993. Influence of glucocorticoids on lipolysis stimulated by fasting and liver function in cows. Tieraerztl. Prax. 21:399-403. (In German; abstract in English).

Fürll, M., and I. Leidel. 2002. Studies on the stabilization of health status in peri-parturient cows. Tieraerztl. Umschau 57:423-438. (In German; abstract in English).

Geishauser, T., M. Diederichs, and R. Beuing. 1996. Estimation of the heritability of displacement of the abomasum in Hessian black pied cattle. J. Vet. Med. Ser. A 43:87-92. (In German; abstract in English).

Gerloff, B. J. 2000. Dry cow management for the prevention of ketosis and fatty liver in dairy cows. Vet. Clin. North Am. Food Anim. Pract. 16:283-292.

Gerloff, B. J., and T. H. Herdt. 1984. Hepatic lipidosis from dietary restriction in nonlactating cows. JAVMA 185:223-224.

Gerloff, B. J., T. H. Herdt, and R. S. Emery. 1986a. Relationship of hepatic lipidosis to health and performance in dairy cattle. JAVMA 188:845-850.

Gerloff, B. J., T. H. Herdt, W. W. Wells, R. F. Nachreiner, and R. S, Emery. 1986b. Inositol and hepatic lipidosis. II. Effect of inositol supplementation and time from parturition on serum insulin, thyroxine, and triiodothyronine and their relationship to serum and liver lipids in dairy cows. J. Anim. Sci. 62:1693-1702.

Gilbert, R. O., Y. T. Gröhn, P. M. Miller, and D. J. Hoffman. 1993. Effect of parity on periparturient neutrophil function in dairy cows. Vet. Immunol. Immunopathol. 36:75-82.

Goff, J. P., and R. L. Horst. 1997. Physiological changes at parturition and their relationship to metabolic disorders. J. Dairy Sci. $80: 1260-1268$

Goff, J. P., R. L. Horst, P. W. Jardon, C. Borelli, and J. Wedam. 1996 Field trials of an oral calcium propionate paste as an aid to prevent milk fever in periparturient dairy cows. J. Dairy Sci. 79:378-383.

Gröhn, Y., K. Heinonen, and L. A. Lindberg. 1987. Fat infiltration in the liver of Finnish Ayrshire cows during early lactation. Acta Vet. Scand. 28:143-149.

Gröhn, Y., L. A. Lindberg, M. L. Bruss, and T. B. Farver. 1983. Fatty infiltration of liver in spontaneously ketotic dairy cows. J. Dairy Sci. 66:2320-2328

Gruchy, C. L., G. McCallum, M. P. Vessey, W. H. Parr, and R. Allcroft. 1963. An investigation of the value of five treatments for acetonaemia in Jersey cows. Vet. Rec. 75:183-191.

Gruffat, D., D. Durand, Y. Chilliard, P. Williams, and D. Bauchart. 1997. Hepatic gene expression of apolipoprotein B100 during 
early lactation in underfed, high producing dairy cows. J. Dairy Sci. 80:657-666.

Gruffat, D., D. Durand, B. Graulet, and D. Bauchart. 1996. Regulation of VLDL synthesis and secretion of the liver. Reprod. Nutr. Dev. $36: 375-389$

Grum, D. E., J. K. Drackley, and J. H. Clark. 2002. Fatty acid metabolism in liver of dairy cows fed supplemental fat and nicotinic acid during an entire lactation. J. Dairy Sci. 85:3026-3034.

Grum, D. E., J. K. Drackley, R. S. Younker, D. W. LaCount, and J. J. Veenhuizen. 1996. Nutrition during the dry period and hepatic lipid metabolism of periparturient dairy cows. J. Dairy Sci. 79:1850-1864.

Grummer, R. R. 1993. Etiology of lipid-related metabolic disorders in periparturient dairy cows. J. Dairy Sci. 76:3882-3896.

Guard, C. L. 1994. Costs of clinical disease in dairy cows. In Proc. Ann. Cornell Conf. Vet. Cornell Univ., Ithaca, NY.

Hamada, T., T. Ishii, and S. Taguchi. 1982. Blood changes of spontaneously ketotic cows before and four hours after administration of glucose, xylitol, 1,2-propanediol, or magnesium propionate. J. Dairy Sci. 65:1509-1513.

Haraszti, J., G. Huszenicza, L. Molnár, E. Ivanits, and J. Fekete. 1982. Studies on the postpartum sexual function of "fatty" cows in the dry period (so-called "fat cow syndrome"). Magyar Állatorv. Lapja 37:199-209. (In Hungarian; abstract in English).

Harris, H. W., J. E. Gosnell, and Z. L. Kumwenda. 2000. The lipemia of sepsis: Triglyceride-rich lipoproteins as agents of innate immunity. J. Endotoxin Res. 6:421-430.

Hartwell, J. R., M. J. Cecava, and S. S. Donkin. 2000. Impact of dietary rumen undegradable protein and rumen-protected choline on intake, peripartum liver triacylglyceride, plasma metabolites and milk production in transition dairy cows. J. Dairy Sci. 83:2907-2917.

Hayirli, A., S. J. Bertics, and R. R. Grummer. 2002. Effects of slowrelease insulin on production, liver triglyceride and metabolic profiles of Holsteins in early lactation. J. Dairy Sci. 85:2180-2191.

Heinonen, K., Y. Gröhn, L. A. Lindberg, and M. Alanko. 1987. The effect of mild fat infiltration in the liver on the fertility of Finnish Ayrshire cows. Acta Vet. Scand. 28:151-155.

Herdt, T. H. 1991. Relationship of fat metabolism to health and performance in dairy cattle. Bovine Pract. 26:92-95.

Herdt, T. H. 2000. Ruminant adaptation to negative energy balance. Influences on the etiology of ketosis and fatty liver. Vet. Clin. North Am. Food Anim. Pract. 16:215-230.

Herdt, T. H., J. Liesman, B. Gerloff, and R. Emery. 1983. Reduction of serum triacylglycerol-rich lipoprotein concentrations in cows with hepatic lipidosis. Am. J. Vet. Res. 44:293-296.

Higgins, R. J., and W. S. Anderson. 1983. Fat cow syndrome in a British dairy herd. Vet. Rec. 113:461-463.

Hill, A. W., I. M. Reid, and R. A. Collins. 1985. Influence of liver fat on experimental Escherichia coli mastitis in periparturient cows. Vet. Rec. 117:549-551.

Hippen, A. R., P. She, J. W. Young, D. C. Beitz, G. L. Lindberg, L. F. Richardson, and R. W. Tucker. 1999. Alleviation of fatty liver in dairy cows by 14-day intravenous infusions of glucagon. J. Dairy Sci. 82:1139-1152.

Hoeben, D., C. Burvenich, A.-M. Massart-Leén, M. Lenjou, G. Nijs, D. van Bockstaele, and J.-F. Beckers. 1999. In vitro effect of ketone bodies, glucocorticosteroids and bovine pregnancy-associated glycoprotein on cultures of bone marrow progenitor cells of cows and calves. Vet. Immunol. Immunopathol. 68:229-240.

Holtenius, P., and K. Holtenius. 1996. New aspects of ketone bodies in energy metabolism of dairy cows: A review. Zentralbl. Veterinaermed. Reihe A 43:579-587.

Johannsen, U., S. Menger, R. Staufenbiel, and N. Rossow. 1992. Experimental investigations on hepatic lipidosis of dairy cows during feed restriction. Mh. VetMed. 47:567-577. (In German; abstract in English).

Johannsen, U., S. Menger, R. Staufenbiel, and N. Rossow. 1993. Investigations on morphology and function of the liver of highyielding cows two weeks post partum. Dtsch. Tieraerztl. Wochenschr. 100:177-181. (In German; abstract in English).
Johannsen, U., A. Schäfer, and A. Uhlig. 1988. Studies into peripartal liver function of dairy cows. Third communication: Infiltration of lipids in liver-occurrence and dynamics. Arch. Exp. Vetmed. 42:118-133. (In German; abstract in English).

Johnson, R. B. 1954. The treatment of ketosis with glycerol and propylene glycol. Cornell Vet. 44:6-21.

Jonsgård, K., M. Aas Hansen, E. Søgnen, and I. Øverby. 1974. Bovine ketosis. II. Therapy and biological factors of significance for recovery. Nord. Vet. Med. 26:362-369.

Jorritsma, R., H. Jorritsma, Y. H. Schukken, P. C. Bartlett, T. Wensing, and G. H. Wentink. 2001. Prevalence and indicators of post partum fatty infiltration of the liver in nine commercial dairy herds in the Netherlands. Livest. Prod. Sci. 68:53-60.

Jorritsma, R., H. Jorritsma, Y. H. Schukken, and G. H. Wentink. 2000. Relationships between fatty liver and fertility and some periparturient diseases in commercial Dutch dairy herds. Theriogenology 54:1065-1074.

Jorritsma, R., T. Wensing, T. A. M. Kruip, P. L. A. M. Vos, and J. P. T. M. Noordhuizen. 2003. Metabolic changes in early lactation and impaired reproductive performance in dairy cows. Vet. Res. 34:11-26.

Kapp, P., G. Pethes, M. Zsiros, and Z. Schuster. 1979. Contribution to the development of the fatty liver syndrome in high producing dairy cows. Magyar Állartorv. Lapja 34:458-468. (In Hungarian; abstract in English).

Katoh, N. 2002. Relevance of apolipoproteins in the development of fatty liver and fatty liver-related peripartum diseases in dairy cows. J. Vet. Med. Sci. 64:293-307.

Kauppinen, K., and Y. Gröhn. 1984. Treatment of bovine ketosis with invert sugar, glucocorticoids, and propylene glycol. Acta Vet. Scand. 25:467-479.

Kelton, D. F., K. D. Lissemore, and R. E. Martin. 1998. Recommendations for recording and calculation the incidence of selected clinical diseases of dairy cattle. J. Dairy Sci. 81:2502-2509.

Kouider, S., F. E. Kolb, I. Müller, and K. Pfüller. 1978. Studies into behavior of several blood components (glucose, fructose, insulin, lactate, pyruvate, free fatty acids, and inorganic phosphate) and into half-life of monosaccharides in blood plasma following intravenous infusion to ruminants of glucose, fructose, galactose, and invert sugar solutions. Arch. Exp. Vetmed. 32:663-684. (In German; abstract in English).

Kushibiki, S., K. Hodate, H. Shingu, Y. Obara, E. Touno, M. Shinoda, and Y. Yokomizo. 2003. Metabolic and lactatational responses during recombinant bovine tumor necrosis factor- $\alpha$ treatment in lactating cows. J. Dairy Sci. 86:819-827.

Ljubuncic, P., Z. Tanne, and A. Bomzon. 2000. Ursodeoxycholic acid suppresses extent of lipid peroxidation in diseased liver in experimental cholestatic liver disease. Dig. Dis. Sci. 45:1921-1928.

Marcos, E., A. Mazur, P. Cardot, and Y. Rayssiguier. 1990. Serum apolipoproteins B and A-1 and naturally occurring fatty liver in dairy cows. Lipids 25:575-577.

Mazur, A., S. Bazin, and Y. Rayssiguier. 1988. Study of hepatic steatosis at the start of lactation in dairy cows consuming grass silage. Reprod. Nutr. Dev. 28:171-172.

Mazur, A., E. Marcos, and Y. Rayssiguier. 1989. Plasma lipoproteins in dairy cows with naturally occurring severe fatty liver: Evidence of alteration in the distribution of apo A-I-containing lipoproteins. Lipids 24:805-811.

McNamara, J. P. 2000. Integrating genotype and nutrition on utilization of body reserves during lactation of dairy cattle. Pages 353370 in Symposium on Ruminant Physiology. P. B. Cronje, ed. CAB Int., London, UK.

Mehrzad, J., L. Duchateau, S. Pyörälä, and C. Burvenich. 2002. Blood and milk neutrophil chemiluminescence and viability in primiparous and pluriparous dairy cows during late pregnancy, around parturition and early lactation. J. Dairy Sci. 85:3268-3276.

Mills, S. E., D. C. Beitz, and J. W. Young. 1986. Characterization of metabolic changes during a protocol for inducing lactation ketosis in dairy cows. Evidence for impaired metabolism in liver during induced lactation ketosis of dairy cows. J. Dairy Sci. 69:352-370.

Minor, D. J., S. L. Trower, B. D. Strang, R. D. Shaver, and R. R. Grummer. 1998. Effects of nonfiber carbohydrate and niacin on 
periparturient metabolic status and lactation of dairy cows. J. Dairy Sci. 81:189-200.

Mizutani, H., T. Sako, Y. Toyoda, T. Kawabata, N. Urumuhang, H. Koyama, and S. Motoyoshi. 1999. Preliminary studies on hepatic carnitine palmitoyltransferase in dairy cattle with or without fatty liver. Vet. Res. Commun. 23:475-480.

Morrow, D. A., D. Hillman, A. W. Dade, and H. Kitchen. 1979. Clinical investigation of a dairy herd with the fat cow syndrome. JAVMA 174:161-167.

Mudron, P., J. Rehage, K. Qualmann, H. P. Sallmann, and H. Scholz. 1999. A study of lipid peroxidation and vitamin $\mathrm{E}$ in dairy cows with hepatic insufficiency. J. Vet. Med. Ser. A 46:219-224.

Murondoti, A., M. T. Tivapasi, M. J. H. Geelen, T. Wensing, and A. C. Beynen. 2002. The effect of postpartum rumen undegradable protein supplementation on hepatic gluconeogenic enzyme activities in dairy cows with fatty liver. Int. J. Vitam. Nutr. Res. 72:336-340.

Mutsvangwa, T., J. P. Walton, J. C. Plaizier, T. F. Duffield, R. Bagg, P. Dick, G. Vessie, and B. W. McBride. 2002. Effects of a monensin controlled-release capsule or premix on attenuation of subacute ruminal acidosis in dairy cows. J. Dairy Sci. 85:3454-3461.

Nafikov, R. A., B. N. Ametaj, G. Bobe, J. W. Young, and D. C. Beitz. 2002. Prevention of fatty liver in transition dairy cows by glucagon. J. Dairy Sci. 85(Suppl. 1):21. (Abstr.)

Nikov, S., I. Ivanov, S. P. Sineonov, A. Dzhurov, and G. Mikailov. 1981. Liver diseases and their relationship to forestomach function in highly productive cows. Vet. Med. Nauki 18:46-55. (In Bulgarian; abstract in English).

Nurmio, P., K. Roine, T. Juokslahti, and A. Loman. 1974. A study of the effects of nicotinic acid in cattle with special reference to ketosis therapy. Nord. Vet. Med. 26:370-381.

Oba, M., and M. S. Allen. 2003. Effects of intraruminal infusion of sodium, potassium, and ammonium on hypophagia from propionate in lactating dairy cows. J. Dairy Sci. 86:1398-1404.

Ohtsuka, H., M. Koiwa, A. Hatsugaya, K. Kudo, F. Hoshi, N. Itoh, H. Yokota, H. Okada, and S. Kawamura. 2001. Relationship between serum TNF activity and insulin resistance in dairy cows affected with naturally occurring fatty liver. J. Vet. Med. Sci. 63:10211025.

Paulová, J., L. Janecková, L. Novotný, S. Kmošt’ák, and I. Čechová. 1990. Steatosis of liver and its relationship to performance, fertility, energy metabolism and liver function. Biol. Chem. Vet. (Praha) 6:457-465. (In Czech; abstract in English).

Pehrson, B. 1972. The effect of orally administered glycogenic substance to dairy cows. Nord. Vet. Med. 24:409-426. (In Swedish; abstract in English).

Pickett, M. M., M. S. Piepenbrink, and T. R. Overton. 2003. Effects of propylene glycol or fat drench on plasma metabolites, liver composition, and production of dairy cows during the periparturient period. J. Dairy Sci. 86:2113-2121.

Piepenbrink, M. S., and T. R. Overton. 2003. Liver metabolism and production of cows fed increasing amounts of rumen-protected choline during the periparturient period. J. Dairy Sci. 86:17221733.

Pinotti, L., A. Baldi, I. Politis, R. Rebucci, L. Sagalli, and V. Dell'Orto. 2003. Rumen-protected choline administration to transition cows: Effects on milk production and vitamin E status. J. Vet. Med. Ser. A 50:18-21.

Quaghebeur, D., and W. Oyaert. 1971. Effect of chloral hydrate and related compounds on the fermentation of glucose by rumen bacteria. Zentralbl. Veterinaermed. Reihe A 18:55-63.

Rayssiguier, A., A. Mazur, E. Gueux, I. M. Reid, and C. J. Roberts. 1988. Plasma lipoproteins and fatty liver in dairy cows. Res. Vet. Sci. 45:389-393.

Rehage, J., C. Meier, M. Kaske, and H. Scholz. 2001. Changes in the amino acid ratio and ammonia concentration in plasma and cerebrospinal fluid of dairy cows suffering from hepatosteatosis and liver failure. J. Dairy Sci. 84(Suppl. 1):152. (Abstr.)

Rehage, J., M. Mertens, N. Stockhofe-Zurwieden, M. Kaske, and H. Scholz. 1996. Post surgical convalescence of dairy cows with left abomasal displacement in relation to fatty liver. Schweiz. Arch. Tierheilkd. 138:361-368.
Rehage, J., K. Qualmann, C. Meier, N. Stockhofe-Zurwieden, M. Hoeltershinken, and J. Pohlenz. 1999. Total serum bile acid concentrations in dairy cows with fatty liver and liver failure. Dtsch. Tieraerztl. Wochenschr. 106:126-129.

Reid, I. M. 1980. Incidence and severity of fatty liver in dairy cows. Vet. Rec. 107:281-284.

Reid, I. M., and R. A. Collins. 1980. The pathology of post-parturient fatty liver in high-yielding dairy cows. Invest. Cell Pathol. $3: 237-249$

Reid, I., S. Dew, R. Collins, M. Ducker, G. Bloomfield, and S. Morant. 1983. The relationship between fatty liver and fertility in dairy cows: A farm investigation. J Agric. Sci. (Camb.) 101:499-502.

Reid, I., and J. Roberts. 1982. Fatty liver in dairy cows. In Pract. $11: 164-169$

Reid, I. M., C. J. Roberts, R. J. Treacher, and L. A. Williams. 1986. Effect of body condition at calving on tissue mobilization, development of fatty liver and blood chemistry of dairy cows. Anim. Prod. 43:7-15.

Rukkwamsuk, T., T. Wensing, and M. J. H. Geelen. 1998. Effect of overfeeding during the dry period on regulation of adipose tissue metabolism in dairy cows during the periparturient period. J. Dairy Sci. 81:2904-2911.

Rukkwamsuk, T., T. Wensing, and M. J. H. Geelen. 1999a. Effect of fatty liver on hepatic gluconeogenesis in periparturient dairy cows. J. Dairy Sci. 82:500-506.

Rukkwamsuk, T., T. Wensing, and M. J. H. Geelen. 1999b. Effect of overfeeding during the dry period on the rate of esterification in adipose tissue of dairy cows during the periparturient period. J. Dairy Sci. 82:1164-1169.

Rukkwamsuk, T., T. Wensing, and T. A. M. Kruip. 1999c. Relationship between triacylglycerol concentration in the liver and first ovulation in postpartum dairy cows. Theriogenology 51:1133-1142.

Saarinen, P., and J. C. Shaw. 1950. Studies on ketosis in dairy cattle. XIII. Lipids and ascorbic acid in the liver and adrenals of cows with spontaneous and fasting ketosis. J. Dairy Sci. 33:515-525.

Sakai, T., T. Hayakawa, M. Hamakawa, K. Ogura, and S. Kubo. 1993. Therapeutic effects of simultaneous use of glucose and insulin in ketotic dairy cows. J. Dairy Sci. 76:109-114.

Sakai, T., M. Hamakawa, and S. Kubo. 1996. Glucose and xylitol tolerance tests for ketotic and healthy dairy cows. J. Dairy Sci. 79:371-377.

Schäfer, M., J. Athenstädt, D. Schulz, D. Silbermann, and M. Sproßmann. 1975. Comparative studies into action of some preparations recommended for treatment of bovine ketosis and their effects on blood sugar. Mh. VetMed. 30:92-96. (In German; abstract in English).

Schäfer, M., A. Uhlig, and U. Johanssen. 1988. Liver function of dairy cows during the peripartum period. I. Generation of subclinical liver function disorders by intensive feeding during advanced pregnancy. Arch. Exp. Vetmed. 42:100-107. (In German; abstract in English).

Schäfer, M., M. Fürll, U. Johannsen, W. Ehrentraut, W. Deckert, and D. Geinitz. 1991. Behavior of clinico-chemical blood parameters of dairy cow, depending on fat level in liver. Mh. VetMed. 46:666669. (In German; abstract in English).

Schultz, L. H. 1952. Treatment of ketosis in dairy cattle with sodium propionate. Cornell Vet. 42:148-155.

Shaw, J. C. 1956. Ketosis in dairy cattle. J. Dairy Sci. 38:402-433.

Shaw, J. C., R. C. Powell, Jr., and G. C. White. 1942. Studies on ketosis in dairy cattle. IV. The effect of glucose therapy and pasture feeding in cases of clinical ketosis. JAVMA 100:473-478.

She, P., A. R. Hippen, J. W. Young, G. L. Lindberg, D. C. Beitz, L. F. Richardson, and R. W. Tucker. 1999. Metabolic responses of lactating dairy cows to 14-day intravenous infusions of glucagon. J. Dairy Sci. 82:1118-1127.

Sheldon, I. M., D. E. Noakes, A. N. Rycroft, D. U. Pfeiffer, and H. Dobson. 2002. Influence of uterine bacterial contamination after parturition on ovarian dominant follicle selection and follicle growth and function in cattle. J. Reprod. Fertil. 123:837-845.

Shi, J., G. E. Gilbert, Y. Kokubo, and R. Ohashi. 2001. Role of the liver in regulating numbers of circulating neutrophils. Blood 98:1226-1230. 
Shpigel, N., R. Chen, Y. Avidar, and E. Bogin. 1996. Use of corticosteroids alone or combined with glucose to treat ketosis in dairy cows. JAVMA 208:1702-1704.

Smith, T. R., A. R. Hippen, D. C. Beitz, and J. W. Young. 1997. Metabolic characteristics of induced ketosis in normal and obese dairy cows. J. Dairy Sci. 80:1569-1581.

Staufenbiel, R., U. Johannsen, H. Dargel, and N. Rossow. 1992. Experimental investigations about fatty liver of dairy cows after feed restriction. Mh. VetMed. 47:559-566. (In German; abstract in English).

Stöber, M., and H. Scholz. 1991. Treatment of dairy cow for lipomobilization syndrome. Mh. VetMed. 46:563-566. (In German; abstract in English).

Stockdale, C. R. 2001. Body condition at calving and the performance of dairy cows in early lactation under Australian conditions: A review. Aust. J. Exp. Agric. 41:823-839.

Stöckl, W., K. Onderscheka, and M. K. Zacherl. 1969. Rapidity and duration of the effect of corticoid preparations. Wien. Tieraerztl. Mschr. 56:229-232. (In German; abstract in English).

Strang, B. D., S. J. Bertics, R. R. Grummer, and L. E. Armentano. 1998a. Effect of long-chain fatty acids on triglyceride accumulation, gluconeogenesis, and ureagenesis in bovine hepatocytes. J. Dairy Sci. 81:728-739.

Strang, B. D., S. J. Bertics, R. R. Grummer, and L. E. Armentano. 1998b. Relationship of triglyceride accumulation to insulin clearance and hormonal responsiveness in bovine hepatocytes. J. Dairy Sci. 81:740-747.

Studer, V. A., R. R. Grummer, S. J. Bertics, and C. K. Reynolds. 1993. Effect of prepartum propylene glycol administration on periparturient fatty liver in dairy cows. J. Dairy Sci. 76:29312939 .

Suriyasathaporn, W., C. Heuer, E. N. Noordhuizen-Stassen, and Y. H. Schukken. 2000. Hyperketonemia and the impairment of udder defense: A review. Vet. Res. 31:397-412.

Szuster-Ciesielska, A., J. Filar, and M. Kandefer-Szerszen. 1995. Depression of interferon production in leukocytes of cows with fat mobilization syndrome. Arch. Immunol. Ther. Exp. (Warsz.) 43:61-65.

Tempelman, R. J., P. M. Saama, A. E. Freeman, S. C. Kelm, A. L. Kuck, M. E. Kehrli, Jr., and J. L. Burton. 2002. Genetic variation in bovine neutrophil sensitivity to glucocorticoid challenge. Acta Agric. Scand., Sect. A. An. Sci. 52:189-202.

Van den Top, A. M., M. J. H. Geelen, T. Wensing, G. H. Wentink, A. T. van't Klooster, and A. C. Beynen. 1996. Higher postpartum hepatic triacylglycerol concentrations in dairy cows with free rather than restricted access to feed during the dry period are associated with lower activities of hepatic glycerolphosphate acyltransferase. J. Nutr. 126:76-85.

Veenhuizen, J. J., J. K. Drackley, M. J. Richard, T. P. Sanderson, L. D. Miller, and J. W. Young. 1991. Metabolic changes in blood and liver during development and early treatment of experimental fatty liver and ketosis in cows. J. Dairy Sci. 74:4238-4253.

Vicini, J. L., F. C. Buonomo, J. J. Veenhuizen, M. A. Miller, D. R. Clemmons, and R. J. Collier. 1991. Nutrient balance and stage of lactation affect response of insulin, insulin-like growth factors I and II, and insulin-like growth factor binding protein 2 to somatotropin administration in dairy cows. J. Nutr. 121:1656-1664.

Wada, Y., M. Muto, and K. Matsuura. 1995. Prognosis of cows with displaced abomasum and fatty infiltration of the liver. J. Jpn. Vet. Med. Assoc. 48:387-390. (In Japanese; abstract in English).

Waterman, R., J. W. Schwalm, and L. H. Schultz. 1972. Nicotinic acid treatment of bovine ketosis I. Effects on circulatory metabolites and interrelationships. J. Dairy Sci. 55:1447-1453.

Wensing, T., T. Kruip, M. J. H. Geelen, G. H. Wentink, and A. M. van den Top. 1997. Postpartum fatty liver in high-producing dairy cows in practice and in animal studies. The connection with health, production and reproduction problems. Comp. Haematol. Int. 7:167-171.

Wentink, G. H., V. P. M. G. Rutten, T. S. G. A. M. van den Ingh, A. Hoek, K. E. Müller, and T. Wensing. 1997. Impaired specific immunoreactivity in cows with hepatic lipidosis. Vet. Immunol. Immunopathol. 56:77-83.

West, H. J. 1990. Effect on liver function of acetonaemia and the fat cow syndrome in cattle. Res. Vet. Sci. 48:221-227.

Woltow, G., R. Staufenbiel, and J. Langhans. 1991. Comparison between histologically and biochemically determined liver fat levels and resulting conclusions. Mh. VetMed. 46:576-582. (In German; abstract in English).

Zerbe, H., N. Schneider, W. Leibold, T. Wensing, T. A. M. Kruip, and H. J. Schuberth. 2000. Altered functional and immunophenotypical properties of neutrophilic granulocytes in postpartum cows associated with fatty liver. Theriogenology 54:771-786.

Zhao, X., B. W. McBride, L. M. Trouten-Radford, and J. H. Burton. 1993. Effects of insulin-like growth factor-I and its analogues on bovine hydrogen peroxide release by neutrophilis and blastogenesis by mononuclear cells. J. Endocrinol. 139:259-265.

Zhou, J., J. Zhang, W. Tian, and C. Zheng. 1997. Study of the effect of fatty liver on fertility in periparturient cows Acta Vet. Zootechn. Sin. 28:115-119. (In Chinese; abstract in English).

Zhu, L. H., L. E. Armentano, D. R. Bremmer, R. R. Grummer, and S. J. Bertics. 2000. Plasma concentration of urea, ammonia, and glutamine around calving, and the relation of hepatic triglyceride, to plasma ammonia removal and blood acid-base balance. J. Dairy Sci. 83:734-740. 